\title{
Solid-State Hydrogen Storage Systems and the Relevance of a Gender Perspective
}

\author{
Erika Michela Dematteis $^{1, *(\mathbb{D}}$, Jussara Barale ${ }^{1}$, Marta Corno ${ }^{1}\left(\mathbb{D}\right.$, Alessandro Sciullo $^{2}$, Marcello Baricco ${ }^{1}(\mathbb{D}$ \\ and Paola Rizzi ${ }^{1}$ (D)
}

1 Department of Chemistry and NIS-INSTM, University of Turin, Via Pietro Giuria 7, 10125 Torino, Italy; jussara.barale@unito.it (J.B.); marta.corno@unito.it (M.C.); marcello.baricco@unito.it (M.B.); paola.rizzi@unito.it (P.R.)

2 Department of Culture, Politics and Society, University of Turin, Lungo Dora Siena 100, 10153 Torino, Italy; alessandro.sciullo@unito.it

* Correspondence: erikamichela.dematteis@unito.it

Citation: Dematteis, E.M.; Barale, J.; Corno, M.; Sciullo, A.; Baricco, M.; Rizzi, P. Solid-State Hydrogen Storage Systems and the Relevance of a Gender Perspective. Energies 2021, 14, 6158. https://doi.org/10.3390/ en14196158

Academic Editors: Paola Russo and Donatella Cirrone

Received: 24 June 2021

Accepted: 2 September 2021

Published: 27 September 2021

Publisher's Note: MDPI stays neutral with regard to jurisdictional claims in published maps and institutional affiliations.

Copyright: (c) 2021 by the authors. Licensee MDPI, Basel, Switzerland. This article is an open access article distributed under the terms and conditions of the Creative Commons Attribution (CC BY) license (https:// creativecommons.org/licenses/by/ $4.0 /)$.

\begin{abstract}
This paper aims at addressing the exploitation of solid-state carriers for hydrogen storage, with attention paid both to the technical aspects, through a wide review of the available integrated systems, and to the social aspects, through a preliminary overview of the connected impacts from a gender perspective. As for the technical perspective, carriers to be used for solid-state hydrogen storage for various applications can be classified into two classes: metal and complex hydrides. Related crystal structures and corresponding hydrogen sorption properties are reviewed and discussed. Fundamentals of thermodynamics of hydrogen sorption evidence the key role of the enthalpy of reaction, which determines the operating conditions (i.e., temperatures and pressures). In addition, it rules the heat to be removed from the tank during hydrogen absorption and to be delivered to the tank during hydrogen desorption. Suitable values for the enthalpy of hydrogen sorption reaction for operating conditions close to ambient (i.e., room temperature and 1-10 bar of hydrogen) are close to $30 \mathrm{~kJ} \cdot \mathrm{mol}_{\mathrm{H} 2}{ }^{-1}$. The kinetics of the hydrogen sorption reaction is strongly related to the microstructure and to the morphology (i.e., loose powder or pellets) of the carriers. Usually, the kinetics of the hydrogen sorption reaction is rather fast, and the thermal management of the tank is the rate-determining step of the processes. As for the social perspective, the paper arguments that, as it occurs with the exploitation of other renewable innovative technologies, a wide consideration of the social factors connected to these processes is needed to reach a twofold objective: To assess the extent to which a specific innovation might produce positive or negative impacts in the recipient socioeconomic system and, from a sociotechnical perspective, to explore the potential role of the social components and dynamics in fostering the diffusion of the innovation itself. Within the social domain, attention has been paid to address the underexplored relationship between the gender perspective and the enhancement of hydrogen-related energy storage systems. This relationship is taken into account both in terms of the role of women in triggering the exploitation of hydrogen-based storage playing as experimenter and promoter, and in terms of the intertwined impact of this innovation in their current conditions, at work, and in daily life.
\end{abstract}

Keywords: energy transition; hydrogen; hydrogen storage; metal hydride; complex hydride; hydrogen tank; social impact; gender

\section{Introduction}

According to the analysis performed by the International Energy Association [1], the electricity consumption per capita increased significantly in last 30 years. At the global level, it changed from 2.06 MWh/capita in 1990 up to 3.26 MWh/capita in 2018, with an increase of $58 \%$ [1], along with a further world increase in electricity demand of $3.5 \%$ during 2019-2021 [2]. This indicator is very different considering different areas, as evidenced from the comparison of the electricity consumption in 2018 in Europe (5.60 MWh/capita), 
Africa (0.57 MWh/capita), and Asia (6.04 MWh/capita) [1]. On the contrary, thanks to the significant introduction of renewable energies, the $\mathrm{CO}_{2}$ emission production per capita increased much less at the global level (i.e., 14\%), changing from $3.88 \mathrm{tCO}_{2} /$ capita in 1990 to $4.42 \mathrm{tCO}_{2}$ /capita in 2018. Even in this case, the values are very different comparing data for 2018 in Europe (5.72 $\mathrm{tCO}_{2} /$ capita), Africa (0.98 $\mathrm{tCO}_{2}$ / capita), and Asia (8.58 $\mathrm{tCO}_{2}$ /capita) [1]. It is worth noting that, considering the values of the same indicator in 1990, a significant decrease was obtained in Europe (-29\%), whereas it moderately increased in Africa (+15\%), and it dramatically increased in Asia (+230\%). On the other hand, global energy-related $\mathrm{CO}_{2}$ emissions reached their maximum of $33.5 \mathrm{Gt}^{\mathrm{CO}_{2}}$ in 2018 , before falling to $31.5 \mathrm{Gt} \mathrm{CO}_{2}$ in 2020 due to the financial crisis and COVID pandemic [3].

The decreased $\mathrm{CO}_{2}$ emissions in Europe can be correlated to an increment in renewable energy production over the last 20 years that replaced the production of electricity by nonrenewable sources. However, increased emissions in Africa and Asia are mainly related to the still dominant production of electricity using nonrenewable sources, even if a significative increment in renewable electricity production has been implemented moving from 58,244 GWh produced in 1990 to 162,686 GWh in 2018 in Africa (+179\%), and moving from 282,578 GWh produced in 1990 to 2,346,209 GWh in 2018 in Asia (+730\%) [1,4]. The impact of RES production can be highlighted considering the evolution over time of the $\mathrm{tCO}_{2}$ produced per MWh consumed, as reported Figure 1.

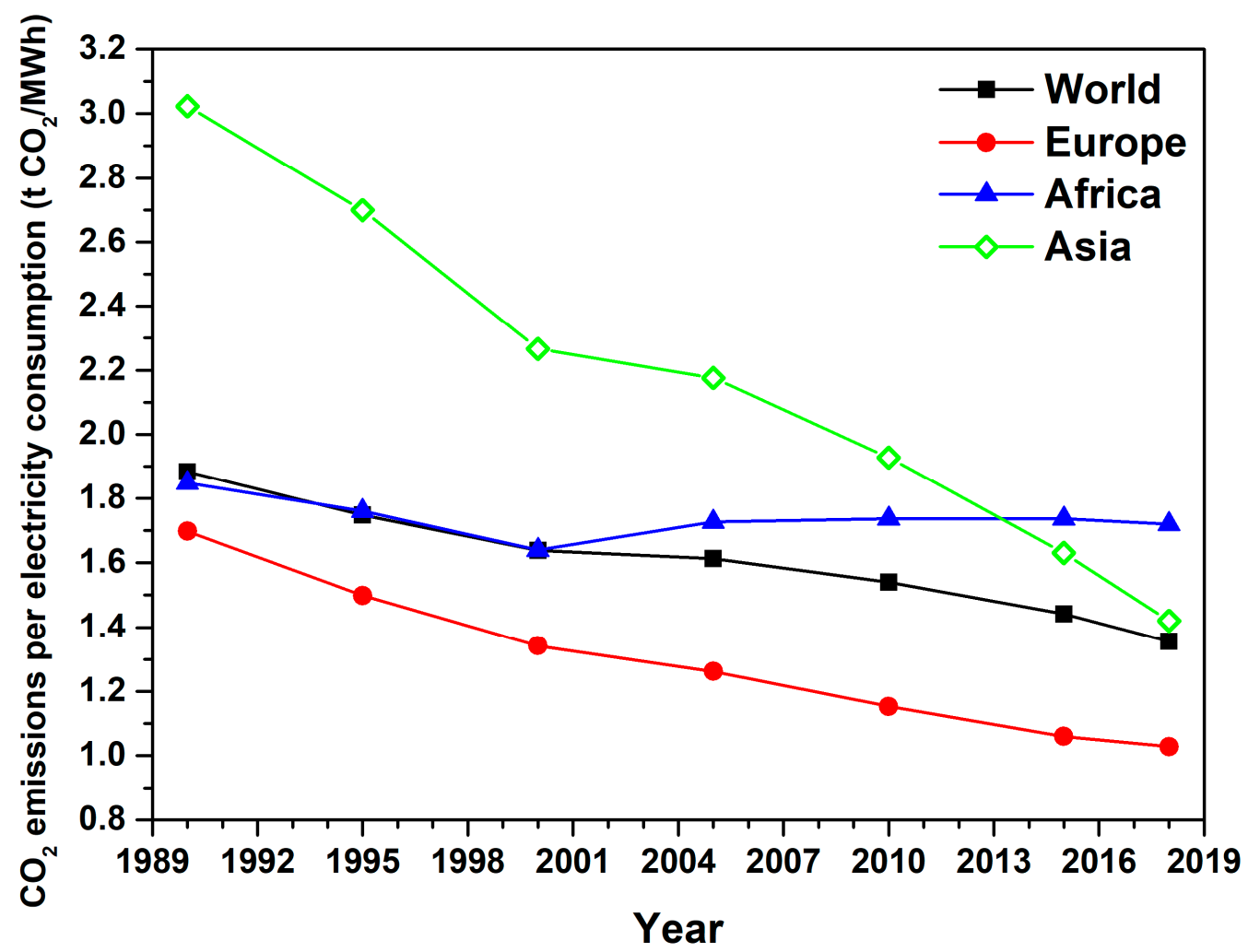

Figure 1. $\mathrm{CO}_{2}$ emissions per electricity consumption in the world, Europe, Africa, and Asia [1].

Europe is the lowest producer of $\mathrm{CO}_{2}$, reaching a value about $1.0 \mathrm{tCO} / \mathrm{MWh}$ in 2018 . By introducing a significative amount of RES in recent years, Asia was able to significantly reduce $\mathrm{CO}_{2}$ emissions per electricity consumption to a value of about $1.4 \mathrm{tCO} / \mathrm{MWh}$ in 2018. On the contrary, Africa slightly increased the $\mathrm{tCO}_{2}$ produced per MWh consumed, reaching a value of about $1.7 \mathrm{tCO}_{2} / \mathrm{MWh}$ in 2018 .

These trends underline the need of implementation of renewable energy production in developing areas that can benefit from increased green energy production while decreasing $\mathrm{CO}_{2}$ emissions. In fact, to get rid of pollution and global temperature increase, it is fundamental to look for an alternative to fossil fuels. The Paris Agreement aims at holding 
the increase in global average temperature below $2{ }^{\circ} \mathrm{C}$ above the preindustrial levels [5]. The Clean Energy for all Europeans Package (CEP) represents the response of the European Union to the Paris Agreement, and its purpose is to drive European Union toward a complete decarbonization by 2050 [6]. This ambitious goal provides for (i) an enhancement of efficiency in all energy-consuming applications, especially in the building sector, (ii) an enhancement of the security of energetic supply, and (iii) help for the integration of renewable energy sources (RES). CEP updated the energetic objectives for 2030 (the Climate and Energy Package of 2009 set the so-called "20-20-20" energy targets) and defined the 2050 goals.

The turning point for renewable exploitation (e.g., wind, solar, and water) can be reached only through the efficient storage of their energy. In fact, renewable energies are highly considered for the distributed production of energy, but their fluctuations in time and geography call for the use of energy storage systems that can deliver energy when needed. The development of good, clean, and efficient materials for energy storage is the bottleneck for using only renewable energies, instead of fossil fuels [7]. It is, therefore, important to design integrated systems at a large scale that allow storing excess energy to meet future demand and utilization at another place or time. The phasing out of the fossil fuels cannot be solved by a single technology but must involve the development of different approaches, which could offer economic and environmental benefits and cover any requirements concerning application, cost, and footprint, while considering its complete life-cycle assessment.

At present, the storage facilities that do exist use pumped hydropower [8], a system that pumps water uphill to a reservoir when excess electricity is available and then lets the water flow downhill through turbines to generate electricity when it is needed. However, this can only be located in very limited areas. Developing new energy storage technologies that are comparable in reliability and cost to pumped hydropower, and that are deployable at any location could enable the storage of vast amounts of electricity anywhere on the grid worldwide and would enable the increased use of renewable electricity generation while maintaining high reliability in electric supply. A continuous flow of clean energy can be obtained with the development of smart grids connected with different energy storage systems, such as batteries or heat storage systems.

One option for electricity storage is the production of green hydrogen from water. In fact, electricity excess can be exploited to produce hydrogen to be used in various applications and in different periods, for example, in power production to satisfy domestic or multiple users.

For this reason, this paper aims at providing an overview of the opportunities and the challenges to be addressed for the available hydrogen-based solutions to become key technologies and boost energy transition, thereby improving energy storage efficiency and smart grids.

Although it is mostly focused on technical aspects, the ambition of the paper is to also shed light on social aspects, considering both the passive perspective of the expected impacts of innovation on different social groups and the active perspective of the role that social dynamics might play in catalyzing the innovation diffusion and acceptance. The literature on sociotechnical systems transition shows, in fact, that no single technological innovation actually exists but instead highlights that innovation processes always involve reciprocal adjustments among the social and technical domains at different levels of the system that a specific innovation is expected to affect when dealing with innovation processes. Therefore, it is always needed to consider the many social, economic, regulatory, and cultural aspects that characterize the system within which the innovation is expected to spread, in order for the innovation itself to "get out from the niche" and exploit its full potential [9-12].

The paper firstly gives, in Section 2, an overview of hydrogen-based technologies for energy storage. In Section 3, an introductory overview of the social aspects to be considered with respect to the spread of innovative solutions for supporting the energy transition 
is provided, with a focus on the relevance of the gender perspective. Then, in Section 4, the paper focuses on available materials for solid-state hydrogen storage in alloys and inorganic materials, and it presents examples of applications of hydrides for hydrogen storage in integrated systems available at the lab scale (units of kilos of hydrogen stored) and at the industrial scale (tens of kilos of hydrogen stored), with attention paid to the flexibility of solid-state-based systems that can be easily integrated to deliver a moderate quantity of hydrogen when and where required. Lastly, in Section 5, some provisional remarks to link the exploitation of hydrogen-based storage solutions with the gender perspective are provided, and a few research proposals providing an empirical basis for exploring this link are suggested.

\section{Hydrogen-Based Solutions for Energy Storage}

The hydrogen cycle from renewables is completely $\mathrm{CO}_{2}$-free, and water is the only by-product [13]. The energy storage can be obtained using hydrogen $\left(\mathrm{H}_{2}\right)$ as a secondary energy vector, which shows several advantages. It can be produced from other primary energy sources, thus being unlimited, it can be stored for a long period of time, and its storage is a key enabling technology for the advancement of hydrogen and fuel cell technologies in applications including stationary power, portable power, and transportation [14,15]. Moreover, the interest in hydrogen as an energy vector is due to its highly exothermic reaction with oxygen to produce only water. Compared to fossil fuels, $1 \mathrm{~kg}$ of $\mathrm{H}_{2}$ has the same energy as $2.4 \mathrm{~kg}$ of $\mathrm{CH}_{4}$ or $2.8 \mathrm{~kg}$ of gasoline. This means that hydrogen has a higher energy-to-weight ratio compared to other fuels. On the other hand, for the energyto-volume ratio, the situation is inverted. Liquid hydrogen has $8.5 \mathrm{MJ} \cdot \mathrm{L}^{-1}$ compared to 32.6 MJ. $\mathrm{L}^{-1}$ of gasoline [16]. This is a drawback for hydrogen storage, because a much higher volume of hydrogen is required to have the same amount of energy provided by most fossil fuels. The aim of hydrogen storage research is to overcome this problem, increasing energy density to limit system volume.

Conventionally, $\mathrm{H}_{2}$ is stored as compressed gas or liquid. It requires significant energy consumption to reach hyperbaric pressures and cryogenic temperatures, resulting non-economically advantageous. On the contrary, the use of hydrogen carriers is a promising solution, since they allow storing $\mathrm{H}_{2}$ at low pressure and close to room temperature, achieving large volumetric densities compared to compressed or liquid hydrogen. Considering a generic hydrogenation reaction of an intermetallic compound $(\mathrm{M})$ to form the corresponding hydride (MH): $\mathrm{M}+\mathrm{x} / 2 \mathrm{H}_{2} \leftrightarrows \mathrm{MH}_{\mathrm{x}}$, the thermodynamics of the equilibrium is characterized by the interrelation among $\mathrm{H}_{2}$ equilibrium pressure $\left(\mathrm{P}_{\text {eq }}\right)$, its concentration (C) in the carrier, and temperature (T), which is described in PCT diagrams. The $P_{\text {eq }}$ is given as a function of temperature by the Van 't Hoff equation, $P_{e q}=\Delta H / R T-\Delta S / R$, where $\Delta \mathrm{H}$ and $\Delta \mathrm{S}$ are the standard enthalpy and entropy of the reaction, respectively, and $\mathrm{R}$ is the gas constant. The kinetic properties of $\mathrm{H}_{2}$ sorption reactions determine the rate at which practical handling can be realized in the material. Moreover, handling hydrogen as hydride results safer than liquid and compressed gas. In addition, the environmental impact evaluation, through a life-cycle analysis (LCA), of the use of solid-state carriers in a tank demonstrated that the environmental impact could be limited with respect to other $\mathrm{H}_{2}$-storage technologies [17,18].

The energy produced by a renewable source (e.g., sun and wind) is used to produce $\mathrm{H}_{2}$ from water through an electrolyzer. The gas is then stored in the designed tank using a carrier. A heat storage system allows collecting solar heat, which can be used during the desorption event to release hydrogen from the MH. Finally, the released green $\mathrm{H}_{2}$ supplies a fuel cell (FC) producing electricity to refill electric vehicles or feed stationary fuel cells for on-demand electricity production, in order to meet the needs of end users (either prosumers or energy communities). The flows of hydrogen, heat, and electricity during hydrogen production and use are described in Figure 2a,b, respectively. However, the hydrogen cycle, from its production to its final use, is characterized by the efficiencies of different technologies, which results in a loss of energy during its use, but provides green 
and flexible storage and use of RES. The processes basically involve three steps: production, logistics, and use. The production of hydrogen by electrolysis of water involves the transformation from a liquid phase to a gas phase, with an efficiency that strongly depends on the technology used, but which can reach values up to about $85 \%$. The logistics of the gaseous hydrogen produced (i.e., its storage and distribution) is related to its compression, liquefaction, or interaction with an appropriate carrier, all processes that involve a loss of energy, with efficiencies up to about $85 \%$. Lastly, its use in combination with oxygen in a fuel cell allows electricity to be produced where and when needed. A large variety of fuel cells are available, characterized by different efficiencies, typically around $50 \%$, but which can reach values up to $70 \%$.

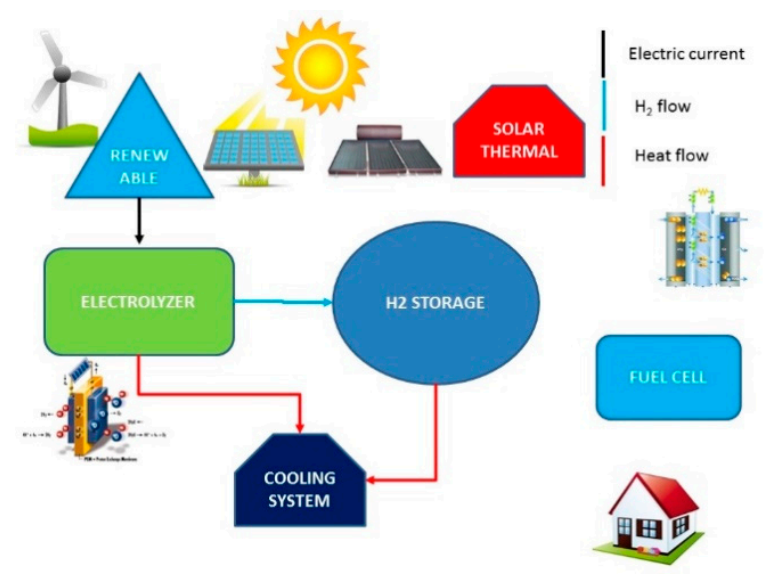

(a)

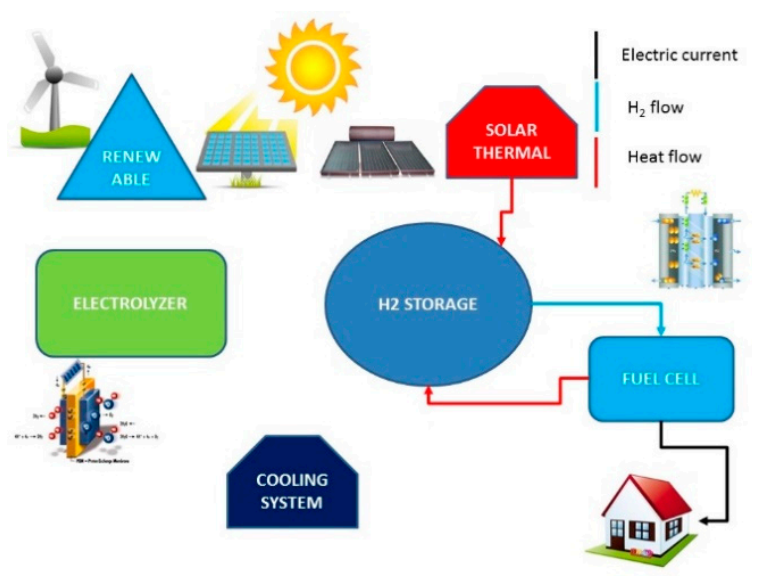

(b)

Figure 2. Flow of hydrogen, heat, and electricity during hydrogen production (a) and use (b).

Considering bottlenecks in energy storage systems, potential technological applications using hydrogen as a carrier in an $\mathrm{MH}$-based system are expected to provide practical operation conditions at pressures below 50 bar and temperatures below $120^{\circ} \mathrm{C}$, including the solar thermal energy contribution to the management of the hydrogen storage system. The main drawback in using $\mathrm{MH}$ operating close to ambient temperature and pressure for hydrogen handling is the gravimetric capacity, being made of transition metals (e.g., $1.3 \mathrm{wt} . \%$ hydrogen for $\mathrm{LaNi}_{5}$ ). Achieving hydrogen capacity close to $2 \mathrm{wt} . \%$ in mild pressure and temperature conditions is also important for stationary applications, because it lowers the cost of $\mathrm{MH}$ per $\mathrm{kg} \mathrm{H}_{2}$. For these reasons, it is necessary to define and design innovative green hydrogen (i.e., produced by non-programmable renewable sources) storage systems, aimed at small-scale users in the civil sector (vehicles, individual houses, condominiums, etc.).

In order to allow for an even more intense exploitation of nonprogrammable renewable sources (sun and wind) in the electricity generation system, it is of fundamental importance to develop distributed generation, and end users must be encouraged to install energy production systems equipped with energy storage, thus becoming prosumers.

As for the end users, it is worth highlighting that prosumers (both as individual households and collective initiatives, such as energy co-ops and communities) have been gaining more and more relevance over the past two decades as a catalyzer for the diffusion of renewable technologies, mainly triggered by the feed-in-tariff incentive schemes in many EU countries [19]. Again, a major challenge that prosumers and energy communities have to face for being actually able to satisfy their own energy demand is the discontinuity of power production from RES. Therefore, hydrogen-related storage solutions can play a crucial role in fostering their diffusion and development, thus making the national energy system able to exploit the funding and policy opportunities coming from the extraordinary convergence of the emergency funds provided by Next Gen EU and the policy framework 
resulting from the national transposition of the EU directives on Energy Market and Renewables [20,21].

Therefore, electricity prosumers and energy communities indeed could be able in the near future to play a central role as an integral part of the electric system, for the spreading of hydrogen technologies and for the overall energy transition, by reducing network losses, by encouraging the implementation of innovative technologies, and by reducing pollutant emissions and energy import, thanks to energy self-production.

Basic and applied research and knowledge on new classes of multifunctional materials will lead the way for the development of such flexible and efficient energy storage methods, the key to a reliable clean electricity supply as reviewed in the present paper, focusing on hydrogen storage technologies and examples of integrated solid-state hydrogen storage systems presented so far at the lab scale and up to the storage of tens kilos of hydrogen (industrial scale).

\section{Social Aspects of Energy Transition: A Sociotechnical System and Gender Perspective}

The centrality of women in the transition processes has entered the international policy agenda for sustainability. At the last United Nations Climate Change Conference (UNCCC), governments approved the Gender Action Plan (GAP), recognizing the importance of equally involving men and women in climate action for an efficient and equal energy transition that will ensure human rights-based and gender-just implementation in the energy transition [22]. With the GAP, we have entered in a new era in which we must enable women's leadership in decision making at all levels of society. By empowering women and girls, we can both address a right issue and give ourselves a better chance to meet the Sustainable Development Goals and the Paris Agreement. The calls for gender equality and women's empowerment were clearly established. As a matter of fact, it has been evidenced that the effectiveness of energy policies improves when gender is acknowledged, through the optimization of outcomes for all the actors involved in the energy system, as highlighted by some policy design approaches such as women in development, gender in development, transformative approach, intersectional approach, and social justice [23]. In this section, we argue why the engagement of women in the transition trajectories and strategies, highly underestimated by policymakers and underexplored by researchers, needs to be carefully considered in order to mitigate the related social impacts and to foster the transition to renewables itself.

\subsection{The Sociotechnical System Framework for Sustainability Innovation}

Climate change is making our world overall less safe for the entire biosphere. Human beings (and human culture and societies) are at risk of being overwhelmed by this global process that they consistently contribute to trigger. Both the increase in the frequency and magnitude of catastrophic events and the negative trends in environmental assets, such as temperature, droughts, and pollution, might produce economic and social negative impacts, able to affect individuals and social groups, thereby hampering and challenging the current social order. A changing climate, therefore, affects all living beings; however, as for the most delicate natural ecosystems, it is the world's poorest and most vulnerable groups, such as the elderly, migrants, and indigenous groups (and especially women and girls within these groups), who withstand the worst of environmental, economic, and social shocks.

The energy transition is an essential component of the climate action and there is a high need for the consideration of social aspects and dynamics as a crucial component of the transformation of energy systems, not only from the passive perspective of the social risks connected to the impacts of the transition process and the ambition to reduce social problems such as energy security, energy poverty, and the gender gap, but also, and even more so, in terms of the relevance that the social factors (culture, values, education ... ) and dynamics (interaction, solidarity, imitation ... ) might play in fostering the transition process, in contexts shaped by the interaction of many nontechnical aspects (regulations, market structures, policy and planning, financial tools ... ). The sociotechnical system (STS) 
approach seems well suited to consider all these nontechnical aspects and dynamics, and it has been gaining relevance for the past two decades in the innovation and sustainability literature as a comprehensive framework able to address the changes in societal subsystems (such as energy, mobility, and agro-food) that are needed to deal with sustainability challenges. By using the label STS, we make reference to an ensemble of technological and social components interacting in an environment for fulfilling a specific objective that cannot be reached by the single technological or social component acting alone [24]. On the basis of this definition, it is easy to find in energy systems the basic feature of an STS: the objective is to provide usable energy; the social component is the ensemble of rules, institutions, and actors, as well as their behaviors, values, and interactions; the technical component is the wide range of technologies available for producing, distributing, using, and storing energy. The energy transition is, by nature, a sociotechnical transition where social innovation (in rules, behaviors, policies, organizational models ... ) is as important as technological innovation [25].

When it comes to describing sociotechnical system transitions, the most widely adopted framework considers three levels to describe the innovation process (multilevel perspective-MLP): $[24,26]$

1. Landscape (macroscale), which considers the sociotechnical setting and megatrends, the wider exogenous environment of macroeconomics, deep cultural patterns, and macropolitical developments, and which usually changes slowly;

2. Regime (mesoscale) or the assemblage of networks (of actors and social groups) and rules (formal, normative and cognitive) that guide the activities of actors, as well as material and technical elements, and that enable and constrain actors. In practice, it includes dominant practices, organizational settings, public policy, and market structure;

3. Niche (microscale), which involves individual actors and small areas for innovation where novelties emerge in an environment protected from mainstream market selection.

STS transitions only come about when developments at all three levels link up and reinforce each other and some inertia in these transitions may be generated from the meso-level due to path dependence on its three dimensions.

Within this social turn in the transition research and policy design, our proposal is to address the relevance of adopting a gender perspective to look at this process not only in order to pay attention to the impact that this transition might have, but also by adopting the MLP to assess the extent to which women's engagement might affect each of the three levels and, therefore, the innovation process itself.

\subsection{The Need for a Gender Perspective to Investigate and Foster Innovation in the Energy Field}

So, why are we engaging women and adopting a gender perspective to investigate and design innovation processes in the energy field? As already introduced, women and girls are more vulnerable to the impact of climate change and the related adaptive and transformative policies, especially in developing countries, where women and girls are predominantly responsible for food production, household management, water supply, and energy supply for heating and cooking. As climate change impacts increase, these tasks become more difficult and more time-consuming [27-29]. If we jointly consider the exposure of women to the social impact or energy transition and how important the general social acceptance of new technologies that should replace energy systems based on fossil fuel is, the relevance of women's involvement is straightforward. The social acceptance connected to a fair transition can be performed only by including and empowering minorities in the transformative pathways, and it should include all gender perspectives toward the new energy regime [30].

Yet, owing to their role in organizing social life, women can simultaneously be at the forefront of the solutions to many of the societal concerns connected with energy transition. In both developing and developed countries, they are, for example, early 
adopters of climate-friendly agriculture and clean energy, and they offer solutions and valuable insights into better managing climate risks [31].

To frame and analyze the role of women in the adoption and diffusion of new technologies to support energy transition, as in the case of solid-state hydrogen storage systems, it is useful to adopt the MLP framework.

As for their relevance at the niche scale, where innovation firstly emerges, women's roles in society equip them with an understanding of the cultural and community context, which is useful for introducing behavioral change with regard to energy consumption, starting from the household level [32,33]. Secondly, when it comes to the already introduced prosumer exploitation, with energy consumers becoming energy producers for their selfconsumption and the market, women's role can bridge and play a role as the agent of change in the whole energy system. As a matter of fact, women have high potential for developing and implementing energy solutions locally. This is mainly related to women's different energy dynamics outlooks, decision-making areas, energy needs, responses to crises, or coping mechanisms with respect to men, which lead to more inclusive perspectives toward energy technologies and services that match those dynamics [23]. Lastly, women's role is crucial for spreading the green energy transition through communications at a family and local level, as well as creating networks and supporting mentorship (up to institutional level and policymaking) with a new perspective to engender the energy transition $[34,35]$.

As for their role at the mesoscale of the sociotechnical regime, which refers to the organizational, market, and policy dimensions, women's engagement has shown great potential for triggering sustainable innovation in public and private organizations [36].

Nonetheless, for this involvement to be effective and sustainable, energy policies have to be properly implemented and allocations of time and resources between genders should be levered to further include women as participants of the entire energy supply chain, in order to support energy planners and consumers in making informed energy choices and to acknowledge and support women's livelihood priorities [23,31]. Taking into account gender roles and relations in energy policy design might trigger a shift toward energy justice in implementing availability, affordability, sustainability, intra- and inter-generational equity, and responsibility in the development of energy system infrastructures [23]. On the regime scale of the education system, women's engagement can also trigger remarkable novelties. In the case of solid-state hydrogen storage systems, given the competences required to develop hydrogen-based solutions that go far beyond mere technical engineering and involve other hard sciences (e.g., chemistry and physics) where women are relatively more represented, hydrogen can be a leverage for STEM women's valorization. As a result, this valorization might trigger an increment in women's technical skills and employment in technical role (STEM-related activities).

Lastly, as for the macroscale of the cultural landscape, the design and implementation of more sustainable ways to produce, distribute, and consume energy affect gender equality if women are involved in the process, by hindering stereotypes, levering opportunity and access to education and culture, stimulating energy research to better understand and account for energy transitions, particularly around envisioning a more just transition along political, socioecological, economic, and technical dimensions, and creating more democratic systems and processes [37].

The sociotechnical framework, thus, allows explaining how and why women's empowerment in the energy transition, through their enhanced inclusion in energy access and use and through the strengthening of their role in the energy chain and decision-making processes, can play a decisive role in addressing the impacts of the sustainable transformation in energy systems considering the social, cultural, economic, and political contexts they are embedded in [23].

As a provisional conclusion, it seems clear that the involvement of women in the energy transition is crucial for the transition itself to be properly and fairly implemented. Because, given their role in organizing social life, women are likely to be more affected than men by the negative and positive impacts of the transition (especially in developing 
countries), and they can simultaneously play a role as agents in the energy transition. A woman's perspective offers a more comprehensive perception of the inequalities and power imbalances in the current energy transition [38]. As women take on more leadership roles, they can lead to addressing climate change by promoting a comprehensive sociotechnical transition to renewable energy, redistributing power, with more balanced community and public control over the energy sector benefits and risks, and prioritizing equity and justice with community ownership and distributed governance [39].

\section{Applications of Hydrides for Hydrogen Storage}

\subsection{Hydrides for Energy Storage}

As introduced, the bottleneck for an affordable and efficient storage of RES through hydrogen is related to the development of high-density hydrogen storage and integrated systems. Below, a brief introduction of the selected materials for solid-state hydrogen storage is reported (i.e., pure metals, intermetallic compounds, and complex hydrides) to introduce and discuss realized tanks or integrated system applications. Hydrogen storage by physisorption is also possible in MOFs, nanotubes, graphene, and similar materials as recently summarized in comprehensive reviews and articles on the topic [40-51]; however, these materials were investigated at a research level and never tested in larger prototypes.

Hydrogen may be stored in pure metals or in inorganic compounds, forming metal and complex hydrides [52-55]. In some cases, hydrogen is taken up and released in solid solutions (e.g., $\mathrm{ZrV}_{2}$ ), without changing the crystal structure of the compound, but only increasing the lattice parameters. In contrast, some pure elements (e.g., Mg) [56,57] and intermetallic compounds (e.g., $\mathrm{LaNi}_{5}$ ) [58] form a hydride phase upon hydrogen absorption $[52,53]$.

Considering pure metals, $\mathrm{MgH}_{2}$ is an excellent material due to its high hydrogen storage capacity (i.e., volumetric $\mathrm{H}_{2}$ density of about $130 \mathrm{~kg} \mathrm{H} \cdot \mathrm{m}^{-3}$ and gravimetric $\mathrm{H}_{2}$ density around $7.6 \mathrm{wt} . \%$ ) [56]. According to available thermodynamic databases $\left(\Delta H=-75 \mathrm{~kJ} / \mathrm{mol}_{\mathrm{H} 2}\right.$ and $\left.\Delta S=-130 \mathrm{~J} / \mathrm{mol}_{\mathrm{H} 2} / \mathrm{K}\right)$ [59], the equilibrium dehydrogenation temperature is high, around $297^{\circ} \mathrm{C}$ under 1 bar of $\mathrm{H}_{2}$, and the ab/desorption kinetics is undesirably slow. A summary of $\mathrm{Mg}$ additives used to improve hydrogen sorption properties was discussed by Baran et al. [60]. Another promising elemental metal hydride is aluminum hydride $\left(\mathrm{AlH}_{3}\right)$ [61], characterized by a theoretical gravimetric $\mathrm{H}_{2}$ density of $10.1 \mathrm{wt} . \%$. Other hydrides of pure metals are characterized by extreme conditions for hydrogen sorption reactions (e.g., Li) or by very high costs (e.g., Pd).

A huge number of metal hydrides has been investigated [62], and particularly interesting for hydrogen storage are hydrides based on intermetallic compounds $A_{2} B, A B, A B_{2}$, and $\mathrm{AB}_{5} . \mathrm{A}$ is an element which forms stable hydrides $\left(\mathrm{AH}_{\mathrm{x}}\right)$, e.g., transition metals of the left side of the periodic table or a rare earth metal. On the contrary, B elements form unstable hydrides $\left(\mathrm{BH}_{\mathrm{y}}\right)$, e.g., transition metals of the right side of the periodic table. In this way, the resulting hydride $\mathrm{A}_{m} \mathrm{~B}_{n} \mathrm{H}_{z}$ will have intermediate properties of $\mathrm{AH}_{x}$ and $\mathrm{BH}_{\mathrm{y}}$ [59]. Examples of intermetallic compounds of interest for $\mathrm{H}_{2}$ storage are reported in Table 1 [59].

Table 1. Examples of intermetallic hydrides for solid-state hydrogen storage.

\begin{tabular}{cccc}
\hline Composition & $\boldsymbol{A}$ & $\boldsymbol{B}$ & Compounds \\
\hline $\mathrm{A}_{2} \mathrm{~B}$ & $\mathrm{Mg}, \mathrm{Zr}$ & $\mathrm{Ni}, \mathrm{Fe}, \mathrm{Co}$ & $\mathrm{Mg} \mathrm{Ni}_{2} \mathrm{Mg} \mathrm{Co}_{2}, \mathrm{Zr}_{2} \mathrm{Fe}$ \\
$\mathrm{AB}$ & $\mathrm{Ti}, \mathrm{Zr}$ & $\mathrm{Ni}, \mathrm{Fe}$ & $\mathrm{TiNi}, \mathrm{TiFe}, \mathrm{ZrNi}$ \\
$\mathrm{AB}_{2}$ & $\mathrm{Zr}, \mathrm{Ti}, \mathrm{Y}, \mathrm{La}$ & $\mathrm{V}, \mathrm{Cr}, \mathrm{Mn}, \mathrm{Fe}, \mathrm{Ni}$ & $\mathrm{LaNi}_{2}, \mathrm{YNi}_{2}, \mathrm{YMn}_{2}, \mathrm{ZrCr}_{2}$, \\
$\mathrm{AB}_{3}$ & $\mathrm{La}, \mathrm{Y}, \mathrm{Mg}$ & $\mathrm{Zr}, \mathrm{Co} \mathrm{Zn}_{2}, \mathrm{ZrV}_{2}, \mathrm{TiMn}_{2}$ \\
$\mathrm{AB}_{5}$ & $\mathrm{Ca}, \mathrm{La}, \mathrm{Rare}$ Earth & $\mathrm{Ni}, \mathrm{Cu}, \mathrm{Co}, \mathrm{Pt}, \mathrm{Fe}$ & $\mathrm{LaCo}_{3}, \mathrm{YNi}_{3}, \mathrm{LaMn}_{2} \mathrm{CaNi}_{9}, \mathrm{LaNi}_{5}, \mathrm{CeNi}_{5}, \mathrm{LaCu}_{5}$, \\
& & $\mathrm{LaPt}_{5}, \mathrm{LaFe}_{5}$ \\
\hline
\end{tabular}

A wide variety of $\mathrm{AB}$ compounds have been studied, particularly Ti- and Zr-based. The most known AB compound for hydrogen storage application is TiFe and its modifications, obtained by substituting Ti or Fe with other metals [63]. TiFe has high potential 
for widespread use, since it stores $\mathrm{H}_{2}$ at low pressure and temperature (e.g., $30-70{ }^{\circ} \mathrm{C}$ and 10-20 bar) and has a good cycle stability at low pressure [64,65]. Moreover, it is cheap and nontoxic, while the raw materials are abundant. A drawback of TiFe is its hard activation, which usually requires thermal cycling between room temperature and high temperature (e.g., $400{ }^{\circ} \mathrm{C}$ ) and/or high hydrogen pressure ( $\approx 100$ bar) [65], resulting in real applications being difficult and costly. Mn-substituted TiFe alloys ( $\mathrm{Ti}\left(\mathrm{Fe}_{\mathrm{x}} \mathrm{Mn}_{1-\mathrm{x}}\right)$ have been reported to display easy activation, no changes in gravimetric capacity until $x=0.70$, and decreased plateau pressure, compared to TiFe, thanks to the increase in cell dimension due to the $\mathrm{Mn}$ substitution [66]. Even quaternary alloys can manifest improved hydrogenation properties, as in the case of $\mathrm{Mn}$ and $\mathrm{Cu}$ substitutions in $\mathrm{TiFe}_{0.9}$ [67].

$\mathrm{AB}_{2}$ compounds for hydrogen storage include usually $\mathrm{Ti}$ and/or $\mathrm{Zr}$ as the A-type element, while $\mathrm{B}$ is a transition metal [68]. $\mathrm{AB}_{2}$ compounds have a crystal structure of Laves phases, mainly a hexagonal $\mathrm{MgZn}_{2}$-type (C14), cubic $\mathrm{MgCu}_{2}$-type (C15), and hexagonal $\mathrm{MgNi}_{2}$-type (C36) [69]. Thanks to these types of structures, they have the advantage of showing high $\mathrm{H}_{2}$ gravimetric capacity (up to about 2 wt. $\% \mathrm{H}_{2}$ ), fast kinetics in absorption and desorption, and easy activation [70]. However, they do not show high resistance to gas impurities, because of possible reactions with constituent elements.

Most of the applications based on $\mathrm{AB}_{2}$ compounds are linked to the mobile sector, and most of the compositions are based on $\mathrm{TiMn}_{2}$ [71].

$\mathrm{AB}_{5}$ compounds involve rare earth metals and transition metals, and the most representative composition is $\mathrm{LaNi}_{5}$ [58], which displays fast activation, high reversibility at low temperatures, fast kinetics, good resistance to gas impurities and quite good cycling stability [62,68]. Thanks to their excellent hydrogen sorption properties, $\mathrm{AB}_{5}$ compounds are widely used for hydrogen storage applications, but they are based on critical raw materials (i.e., rare earths) $[72,73]$. $\mathrm{LaNi}_{5}$ has a hexagonal $\mathrm{CaCu}_{5}$-type structure, with space group P6/mmm [74], and, upon hydrogenation, it forms $\mathrm{LaNi}_{5} \mathrm{H}_{\mathrm{x}}$ hydrides (with $5<\mathrm{x}<7$ ). $\mathrm{LaNi}_{5}$ has a hydrogen volumetric capacity of $115 \mathrm{~kg} \mathrm{H} \cdot \mathrm{m}^{-3}$ and a maximum gravimetric capacity of $1.5 \mathrm{wt} . \% \mathrm{H}_{2}$ [75]; pressure composition temperature (PCT) curves display a flat plateau, and hysteresis is limited [76]. Activation is easy and fast and usually involves cycles of hydrogenation and dehydrogenation with pressures and temperatures lower than 100 bar and $100{ }^{\circ} \mathrm{C}$, respectively. In general, substitution of B sites tends to decrease equilibrium pressure, while substitutions of A sites increase it [77].

Recently, attention has been focused on complex hydrides, which are interesting because of their light weight and their high number of hydrogen atoms per metal atom [78]. Complex hydrides can be described by the general chemical formula $A_{x} B_{y} H_{z}$. The A elements are mainly light elements of the first and second groups of the periodic table, which form the cation. The B element could be aluminum, boron, nitrogen, or a transition-metal, which, bonded to hydrogen, forms the complex anion.

Alanates are composed of a complex anion $\left[\mathrm{AlH}_{4}\right]^{-}$or $\left[\mathrm{AlH}_{6}\right]^{3-}$ and respective metal cation, which are salt-like, insulating materials [79]. Depending on the metal cation, theoretical gravimetric capacity is equal to $10.5 \mathrm{wt} \%$ for $\mathrm{LiAlH}_{4}, 5.5 \mathrm{wt} \%$ for $\mathrm{NaAlH}_{4}$, 5.7 wt.\% for $\mathrm{KAlH}_{4}$, and 9.3 wt.\% for $\mathrm{Mg}\left(\mathrm{AlH}_{4}\right)_{2}$ [79]. Kinetics, thermodynamics, and cycling properties of alanates can be tailored through the variation of particle sizes, addition of catalysts (dopants), and doping procedures [80], as in the case of $\mathrm{NaAlH}_{4}(3.7 \mathrm{wt}$.\%) and Ti-doped $\mathrm{NaAlH}_{4}$ (3.0 wt.\%) [81-83].

Borohydrides are inorganic ionic compounds suitable for hydrogen storage in the solid state and they are a multifunctional class of materials that may also be used as fast ion conductors for new types of batteries, gas adsorption, or $\mathrm{CO}_{2}$ capture and recycling. [84,85]. The theoretical hydrogen content of $\mathrm{LiBH}_{4}$ is $18.5 \mathrm{wt} . \%$, i.e., the highest among metal borohydrides, while it is equal to $10.7 \mathrm{wt}$ \% for $\mathrm{NaBH}_{4}, 7.5 \mathrm{wt}$.\% for $\mathrm{KBH}_{4}, 14.9$ wt.\% for $\mathrm{Mg}\left(\mathrm{BH}_{4}\right)_{2}$, and $11.6 \mathrm{wt}$ \% for $\mathrm{Ca}\left(\mathrm{BH}_{4}\right)_{2}$. Observed values are usually lower, depending on the experimental conditions [85]. The borohydride decomposition process involves the intermediate formation of the binary metal hydride and elemental boron or, due to kinetics, the formation of closoboranes $\left(\mathrm{M}_{\mathrm{x}} \mathrm{B}_{10} \mathrm{H}_{10}, \mathrm{M}_{\mathrm{x}} \mathrm{B}_{12} \mathrm{H}_{12}\right)$, which limit the reversibility of the 
process. The thermodynamics and kinetics of hydrogen release and uptake reaction in borohydrides can be tailored by adding a catalyst, doping, or mixing [86-93].

Amides and imides of alkali and alkaline-earth metals in combination with metal hydrides have the potential to meet the needs of on-board hydrogen storage. Lithium amide-imide can form a solid solution that plays a functional role in the hydrogen storage reactions. A review of these materials was recently published by Garroni et al. [94].

Additionally, the formulation of mixtures of metal hydrides and complex hydrides (mainly borohydrides or amide/imide), the so-called reactive hydride composites (RHCs), enables reversible and kinetically/thermodynamically favorable hydrogen desorption/ absorption under moderate temperature and hydrogen pressure conditions $[85,86]$.

Few examples using complex hydrides as solid-state hydrogen storage materials have been tested in lab-scale tanks, and main research efforts investigated combinations of different complex hydrides (evidencing the formation of bimetallic compounds or eutectic melting) and metal halides, playing with cation and anion substitutions. Recent reviews reported RHC mixtures involving alanates, borohydrides, metal hydrides, and metal halides $[40,78,84,85,95,96]$. For establishing further applications of the abovementioned materials for solid-state hydrogen storage in integrated energy systems, the thermodynamic modeling of materials and systems is essential to define and tailor hydrogenation properties and their stability as a function of temperature and pressure in the direction of defining their thermo-fluido-dynamic behavior. Below, an overview of modeling approaches is described, and hydride-based integrated systems available at both the lab scale (storing a hydrogen amount lower than $1 \mathrm{~kg}$ ) and the industrial scale (storing a hydrogen amount higher than $1 \mathrm{~kg}$ ) are presented.

\subsection{Modeling of Hydride-Based Integrated Systems}

A full picture of the thermodynamic properties of a system can be obtained using the CALPHAD approach [97]. The goal of CALPHAD assessments is to obtain a description of the dependence of the free energy of all phases on temperature, pressure, and composition. The interaction parameters can be obtained with a least square procedure, starting from the experimental values of existing phase diagrams and thermodynamic data (Figure 3).

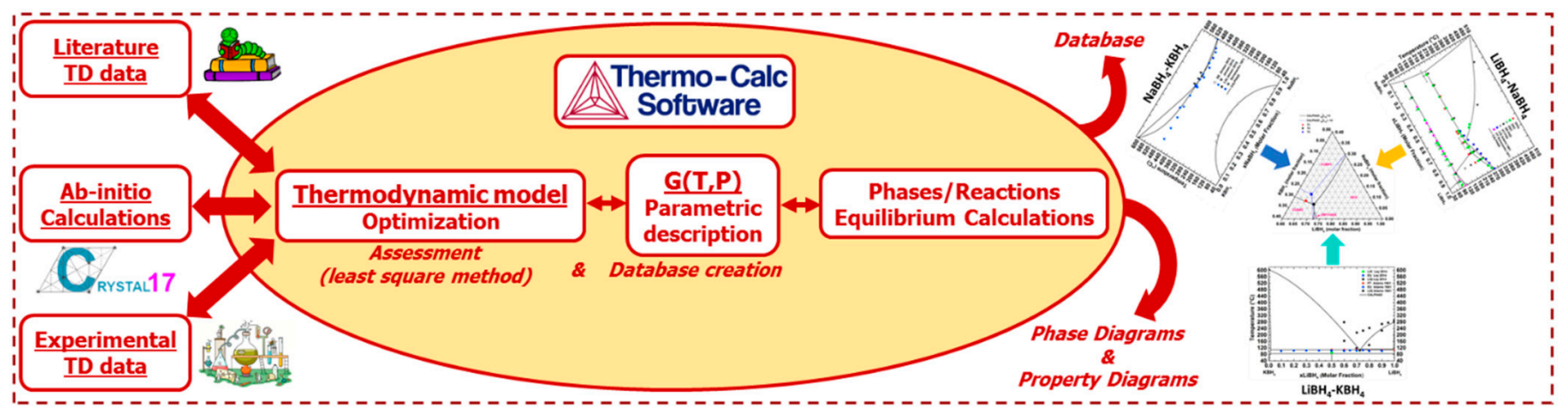

Figure 3. Flowchart of the assessment procedure using the CALPHAD method.

As a consequence, all the thermodynamic functions of the various phases can be derived by optimizing the input data. The basis of the CALPHAD method is the availability of thermochemical data related to the investigated systems. In the absence of experimental information, the output of various thermodynamic or quantum mechanical models can be used [98]. In particular, an estimation of the energy of formation of a compound can be obtained by ab initio modeling. In line with this, calculations have been performed on hydrides using the CRYSTAL program, in its 2009 [99], 2014 [100], and current (2017) [101,102] versions. The CRYSTAL software performs ab initio calculations of the ground-state energy, energy gradient, and electronic wave function and properties (electronic, vibrational, thermodynamic, and elastic) of periodic systems. Hartree-Fock (HF) or Kohn-Sham Hamiltonians, following density functional theory (DFT), are used. CALPHAD assessments of 
various systems have been carried out in recent years for systems of interest for hydrogen storage. In particular, the suggested approach including a combination of CALPHAD and $\mathrm{ab}$ initio modeling has recently been applied to a number of complex hydride systems.

For example, the thermodynamic properties of $\mathrm{LiBH}_{4}-\mathrm{NaBH}_{4}, \mathrm{LiBH}_{4}-\mathrm{KBH}_{4}$, and $\mathrm{NaBH}_{4}-\mathrm{KBH}_{4}$ binary systems have been investigated, and the assessed binary systems have shown good agreement with experimental data (Figure 3) [88]. Ab initio results provided the enthalpy of mixing for the solid solutions on both the lithium- and sodium-rich side. Moreover, a full investigation of the ternary system $\mathrm{LiBH}_{4}-\mathrm{NaBH}_{4}-\mathrm{KBH}_{4}$ was carried out [89]. As for divalent complex borohydrides, calcium [103] and magnesium [104] borohydrides have also been investigated using CALPHAD and ab initio modeling, particularly aiming at the study of halogenation as an alternative for destabilization by changing their bond strength. Concerning the effect on nanostructure in the decomposition of another complex borohydride, i.e., $\mathrm{Ca}\left(\mathrm{BH}_{4}\right)_{2}$, very recent ab initio simulations of thin films were able to highlight the advantages of nanosizing thermodynamics of hydrogen release from metal borohydrides for energy storage applications [105].

Furthermore, the design of a tank for hydrogen storage in the solid state requires, together with the selection and modeling of materials with specific properties, the development of a suitable control of the hydrogenation and dehydrogenation processes. The goal of modeling is to combine the thermodynamic/kinetic properties of the selected materials with a proper design of the tank. To achieve short refueling times in a metal hydride storage tank and appropriate release of hydrogen for coupling to a fuel cell system, it is first necessary to understand the details of the hydrogen charging dynamics in the hydride bed. Hydrogen storage in a hydride vessel is a complex problem, since the heat and mass transfer, fluido-dynamics, and chemical reaction are not independent processes. Therefore, the detailed physical and chemical processes in the storage bed in relation to heat and mass transfer, chemical reaction, and fluid flow are translated into a heterogeneous model, which is solved with the help of computational fluid dynamics (CFD) simulation software.

As an example, MATLAB or PYTHON compiling software can be used in a lumped simulation to estimate and model the design of a metal hydride system, to define the dimension of the system and the thermo-fluido-dynamic processes involved. This modeling approach is usually followed or combined with finite element analysis (FEA) to refine the design of a product in an accurate and reliable way, as well as quickly obtain the physical quantities of interest for optimizing the design, the management of fluid dynamics, and the engineering of the real tank or prototype system to be developed. An example of FEA simulation software is COMSOL.

The implementation of the tank geometry into the program code can be used as a design tool for solid-state hydrogen storage tanks. The key point for the tank design is the use of coupling of hydrogen storage materials with different intrinsic properties, aimed at an internal management of the thermal effects during hydrogen charging and discharging. Usually, metal hydrides have a low thermal conductivity, on the order of 0.3 to $1 \mathrm{~W} \cdot \mathrm{m}^{-1} \cdot \mathrm{K}^{-1}[106]$, and, in many cases, heat transfer is the rate-limiting step in storage systems. Thus, experimental data in combination with numerical methods become necessary to understand the mechanism of heat transfer in the bed in order to improve the design and the efficiency of heat exchangers.

Hydrogen absorption and desorption phenomena are modeled through the solution of differential equations governing processes such as the mass balance of hydrogen and metal, momentum, and energy equations. When the values of all parameters are not available in the literature, the model must be validated by comparing the results of calculations with the data obtained from experiments of hydrogen absorption and desorption. As an example, the value of some critical parameters, such as the heat transfer coefficient and effective thermal conductivity, were estimated using COMSOL for $\mathrm{LaNi}_{4.8} \mathrm{Al}_{0.2}$ powder on the basis of experimental data [107]. The geometry used in modeling is shown in Figure 4a and represents a longitudinal section with two subdomains (one for the porous media and one for the free space), which is surrounded by an isothermal bath. 


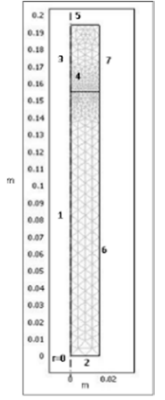

(a)

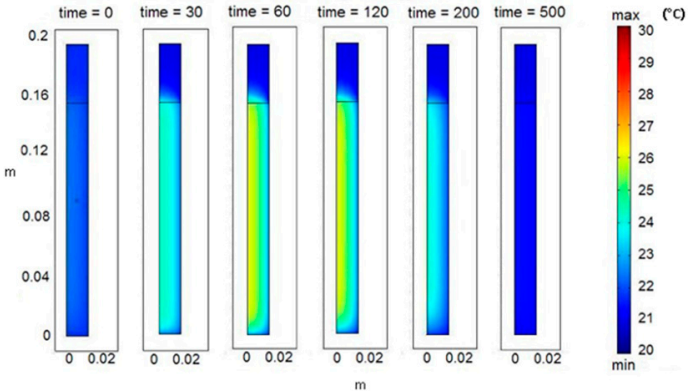

(b)

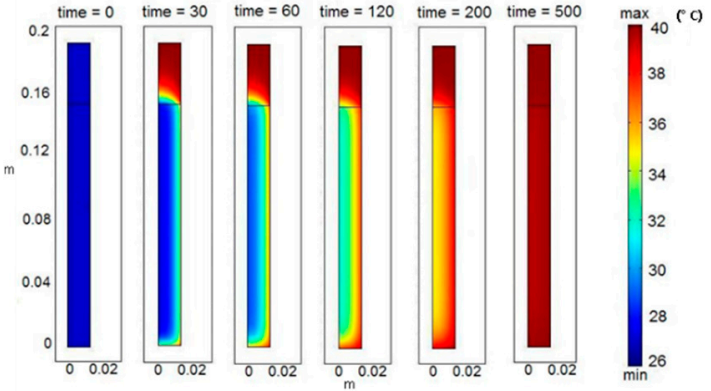

(c)

Figure 4. (a) Schematic view of the domain with unstructured mesh used in the simulation. Temperature distribution in the bed during hydrogen absorption (b) and desorption (c) processes at different times (in seconds).

Once all the parameters have been set [107], it is possible to obtain the time-space evolution of temperature, as shown in Figure $4 \mathrm{~b}$, $\mathrm{c}$ for the hydrogen absorption and desorption processes, respectively. In Figure $4 \mathrm{~b}$, the temperature into the vessel increases in the first $60 \mathrm{~s}$ until it reaches $25^{\circ} \mathrm{C}$ due to the exothermic hydrogen absorption reaction. Later, the temperature of the vessel reaches the equilibrium temperature of the bath. In Figure 4c, the temperature into the vessel decreases in the first $30 \mathrm{~s}$ due to the endothermic hydrogen desorption reaction. As the external bath is fixed at $40^{\circ} \mathrm{C}$, after $30 \mathrm{~s}$, the temperature increases until it reaches equilibrium. As a result, a full description of the thermo-fluido-dynamic processes during hydrogen absorption and desorption become available.

\subsection{Hydride-Based Systems Available at Lab Scale}

In 2019, Bellosta von Colbe et al. reviewed metal hydride-based storage systems for stationary and mobile applications, mainly available at the lab scale and presenting technology's future perspectives [108].

Previously, in 2017, Lototskyy et al. summarized an integrated system realized in the past years, reporting some examples of tanks based on solid-state hydrogen storage materials to be coupled with a fuel cell system at the lab scale [71]. Most of them are based on intermetallic compounds and are demonstrative, prototype, or simulated devices [71]. Reported materials used are mainly based on $\mathrm{AB}_{2}\left((\mathrm{TiZr})(\mathrm{Mn}, \mathrm{Fe}, \mathrm{V})_{2}\right.$-type) and $\mathrm{AB}_{5}\left(\mathrm{LaNi}_{5}-\right.$ type) intermetallic compounds, which are preferred thanks to their low pressure and temperature working conditions, despite their low gravimetric capacity. Few systems use $\mathrm{MgH}_{2}$ or other carriers, including mixtures of hydrides.

Even fewer examples and studies have been reported in the literature regarding complex hydride-based system for solid-state hydrogen storage at the lab scale. Usually, a very limited amount of hydrogen (grams) is successfully and reversibly stored, as demonstrated below [109].

Utz et al. tested and cycled $98 \mathrm{~g}$ of Ce-doped $\mathrm{NaAlH}_{4}$ in a lab-scale tank ensuring fast kinetics and a good gravimetric capacity of $4 \mathrm{wt} . \%$ at $120^{\circ} \mathrm{C}$ upon 36 cycles [110]. Another $0.3 \mathrm{~kg}$ of a Ce-modified sodium alanate tank was realized and tested over 25 cycles, working in the range of $1-100$ bar and $30-168{ }^{\circ} \mathrm{C}$, reaching a capacity as high as $3.7 \mathrm{wt} . \%$ [111]. An overall system description was presented by Pfeifer et al., consisting of four parallel tanks with $0.5 \mathrm{~kg}$ of Ce-doped $\mathrm{NaAlH}_{4}$ in each, coupled with a $1 \mathrm{~kW} \mathrm{H}$-consumption high-temperature proton-exchange membrane fuel cell (HT-PEM FC), a preheater system, and a pump [112]. A cumulative output of $0.8 \mathrm{kWh}$ was reached in a test run at $120^{\circ} \mathrm{C}$, where full material discharging was possible [112].

Usually, in operating conditions, only the first reaction of decomposition can be exploited at $160^{\circ} \mathrm{C}$, as in the case of the Weiss-Ungethüm et al. system [113]. In their study, they successfully coupled an HT-PEM FC with a $0.3 \mathrm{~kg}$ Ce-doped $\mathrm{NaAlH}_{4}$ tank, reversibly storing hydrogen for a capacity equal to $2.24 \mathrm{wt} . \%$, and generating an electrical energy of $660 \mathrm{Wh}$ [113]. 
An aluminum alloy tank containing $1.9 \mathrm{~kg}$ of $\mathrm{Na}_{3} \mathrm{AlH}_{6}$ doped with $4 \mathrm{~mol} . \%$ of $\mathrm{TiCl}_{3}$ and $8 \mathrm{~mol} . \%$ of activated carbon was characterized over 15 cycles by Urbanczyk et al. [114]. The tank operates under $25 \mathrm{bar}$ in absorption and can release $38 \mathrm{~g}$ of hydrogen during desorption, for a gravimetric hydrogen density of $2.0 \mathrm{wt} . \%$ [114]. Mosher et al. built a $3 \mathrm{~kg}$ and $20 \mathrm{~kg} \mathrm{TiCl}{ }_{3}$-doped $\mathrm{NaAlH}_{4}$ tank, reaching a material capacity in large-scale production of about 1 wt.\% [115,116]. Furthermore, a lab-scale tank using Ti-doped $\mathrm{Na}_{3} \mathrm{AlH}_{6}$ synthetized by ball milling was able to store $3.6 \mathrm{~g}$ of hydrogen (gravimetric capacity equal to $1.7 \mathrm{wt} . \%)$ at $177^{\circ} \mathrm{C}$ and 25 bar [117]. The same group developed another prototype tank based on sodium alanates, with a gravimetric reversible density of $2.24 \mathrm{wt} . \%$ coupled with an HT-PEM FC stack with an output power of $260 \mathrm{~W}_{\mathrm{el}}$. The operating temperature range of the stack was $120-190{ }^{\circ} \mathrm{C}$ [118].

A small sodium alanate tank ( $30 \mathrm{~g}$ ) was built and tested by Na Ranong et al., simulating a scaleup to an $8 \mathrm{~kg}$ alanate tank for the STORHY project, together with a preliminary study for scaleup to storing $5 \mathrm{~kg}$ of hydrogen for mobile applications [119]. The STORHY project (2004-2008) [120] developed a high-capacity complex hydride sodium alanate tank, with a reached capacity of $4.5 \mathrm{wt} . \%$. The tank could be successfully cycled and charged up to $80 \%$ in less than $10 \mathrm{~min}$ [121]. Later on, the NESSHY project (2006-2010) developed a sodium alanate tank (doped with $\mathrm{TiCl}_{3}$ and $\mathrm{AlCl}_{3}$ ) with improved gravimetric and volumetric capacity for a total amount of $0.2 \mathrm{~kg}$ of hydrogen stored [122]. Sandia and General Motors have successfully designed, fabricated, and experimentally operated and optimized a vehicle-scale hydrogen storage demonstration system using sodium alanates [123]. The demonstration system module design and the system control strategies were enabled by experiment-based, computational simulations that included heat and mass transfer coupled with chemical kinetics [123].

From the perspective of industrial applications, a lab-scale tank was tested using $98 \mathrm{~g}$ of $\mathrm{Mg}\left(\mathrm{NH}_{2}\right)_{2}-2 \mathrm{LiH}-0.07 \mathrm{KOH}$ reactive composite as hydrogen storage media [124,125]. The tank ran under 60 bar in absorption and at $180-250{ }^{\circ} \mathrm{C}$; the heat management of the system was of fundamental importance for efficient hydrogen delivery and storage [126].

In addition to their use as solid-state hydrogen storage materials, borohydrides can be exploited in direct borohydride fuel cells (DBFCs), a very promising system for portable applications [127], where hydrogen is generated by hydrolysis of complex hydrides. Usually, a DBFC employs an alkaline solution of sodium borohydride $\left(\mathrm{NaBH}_{4}\right)$ as fuel and oxygen or hydrogen peroxide as oxidant. Recent developments in DBFC research were reviewed in [128]. However, such technology is at an infant stage of development, with a strong need for improvement of materials and a lowering of their cost. Kim et al. described a system that combines PEM FC and a reactor for $\mathrm{NaBH}_{4}$ hydrolysis as a hydrogen generator. The PEM FC consumed approximately $1.2 \mathrm{~L} / \mathrm{min}$ of hydrogen to generate the electric power of $100 \mathrm{~W}$ [129]. The main research on tank and system integration exploiting borohydrides in a hydrolysis reaction was reviewed by Ley et al. together with a description of other developed tanks based on thermolysis for hydrogen generation, mostly involving sodium alanates and reactive hydride composites mixtures [109]. Hydrolysis of borohydride has also been considered for one-shot hydrogen production on demand; it is, however, still restricted to niche and limited applications [130,131].

\subsection{Hydride-Based Systems Available at Industrial Scale}

Metal hydrides have been known since the late 1970s as a low-risk option to store hydrogen [108]. Intermetallic compounds are usually commercialized in the form of powder, which is usually obtained by the crash of ingots prepared via melting techniques. In order to improve thermal conductivity, some producers provide powders aggregated by suitable binders in the form of pellets. Usually, metal hydrides powders can be handled in air until their hydrogenation/activation. For industrial-scale hydrogen storage applications (i.e., units of kilos of hydrogen and even more), metal hydride powders are produced at a ton level. Hydrogen storage systems based on hydrides are available on the market, even if real applications are still limited. Some examples are briefly described below. 
Applications for mobility are limited by the low gravimetric density of metal hydrides. Nevertheless, when an increased weight is a benefit for the application, hydrogen storage by metal hydrides becomes an added value. On the contrary, for mobile applications on roads (i.e., automobiles, heavy-duty transport, and trains), compressed gas is preferred for the hydrogen storage.

An important heavy-duty mobile application is a forklift [108]. An $\mathrm{AB}_{2}$ alloy $\left((\mathrm{Ti}, \mathrm{Zr})(\mathrm{Fe}, \mathrm{Cr}, \mathrm{Mn}, \mathrm{Ni})_{2}\right.$ with a Ti:Zr atomic ratio of approximately 0.65:0.35) was developed to work at room temperature and pressure $<10$ bar. The storage system consists of 20 metal hydride containers for a final weight of approximately $200 \mathrm{~kg}$ of metal powder. Each container delivers about 7.5 N.L/min and supplies a PEM FC of about $10 \mathrm{~kW}$.

The maritime sector is interested in limiting pollutant emissions to face climate change, and the use of fuel cells supplied by $\mathrm{H}_{2}$ has found high potential in the last few years. Van Biert et al. recently reviewed fuel cell systems for maritime applications, including hydrogen as a promising energy carrier to be exploited [132]. A special focus on hydrogen storage media in the solid state for submarine applications was reviewed by Fiori et al. [133]. Many other reviews described the development of fuel cell vessels and the potential of hydrogen for maritime and submarine applications [134-138]. Hydrogen-fueled submarines have about $300 \mathrm{~kW} \mathrm{FC}$, and the storage system is based on an $\mathrm{AB}_{2}$ alloy, which works between 20 and $50{ }^{\circ} \mathrm{C}$ [108]. Another example of application in the maritime sector involves the $\mathrm{AB}_{2}$ alloy $\left(\mathrm{Ti}_{0.93} \mathrm{Zr}_{0.05}\right)\left(\mathrm{Mn}_{0.73} \mathrm{~V}_{0.22} \mathrm{Fe}_{0.04}\right)_{2}$ used for the canal boat Ross Barlow, in UK [139], where eight cylinders containing about $30 \mathrm{~kg}$ of metal hydride powder each were used and $4 \mathrm{~kg}$ of $\mathrm{H}_{2}$ were stored and used to supply a $1 \mathrm{~kW}$ PEM FC, which allows $10 \mathrm{~h}$ of operation.

Stationary applications mainly refer to the volumetric density rather than the gravimetric density of the hydrogen carrier. In particular, the final footprint per weight of stored hydrogen becomes the key performance metric to be considered. Most integrated systems are based on $\mathrm{AB}_{5}$ compounds, such as $\mathrm{LaNi}_{5}$ and $\mathrm{LaNi}_{5}$-based alloys. As an example, an automated hydrogen-based auxiliary power unit was developed by Doucet et al. [140], with a storage capacity of about $1 \mathrm{Nm}^{3}$, to be used by a PEM FC of $1 \mathrm{~kW}$. A stationary system commercially available based on an $\mathrm{AB}_{5}$ intermetallic compound is the H2ONE developed in Japan and commercialized by Toshiba [141]. Systems are scaled to be easily installed anywhere, with an $\mathrm{H}_{2}$ storage capacity of $\sim 150 \mathrm{Nm}^{3}$ per module. An example of a stationary application, based on a commercial $\mathrm{LaNi}_{4.8} \mathrm{Al}_{0.2}$ alloy, was developed by Rizzi et al. [142]. The hydrogen tank worked at $60{ }^{\circ} \mathrm{C}$ and it was integrated with a $1 \mathrm{~kW}$ PEM FC. A scheme of the developed tank is reported in Figure 5a, while a general view of the developed system is reported in Figure 5b.

A hydrogen storage system based on an AB intermetallic (i.e., Ti(Fe,Mn)) alloy was developed in South Tyrolean Alps by GKN [143], with a system providing energy for a house, which had no access to the grid. GKN is now launching on the market small, medium, and large hydrogen storage systems based on this technology [144]. At the Brookhaven National Laboratory, engineering-scale tests were performed in the 1970s, and a large TiFe-based system prototype was developed [145-148]. A final optimized tank stored $6 \mathrm{~kg}$ of hydrogen using $405 \mathrm{~kg}$ of TiFe for the storage of off-peak electricity in an integrated system that combined an electrolyzer, hydrogen tank, and fuel cell [149]. In the framework of the European project HyCARE [150,151], supported by FCH-JU, a hydrogen storage system based on AB alloys is planned [152-155]. The aim of the project is to store $\sim 50 \mathrm{~kg}$ of $\mathrm{H}_{2}$ by integrating the storage tank with an electrolyzer upstream and a fuel cell downstream to produce energy for the grid (stationary application). The tank is based on an innovative concept that links hydrogen and heat storage for stationary storage of excess renewable energy. 


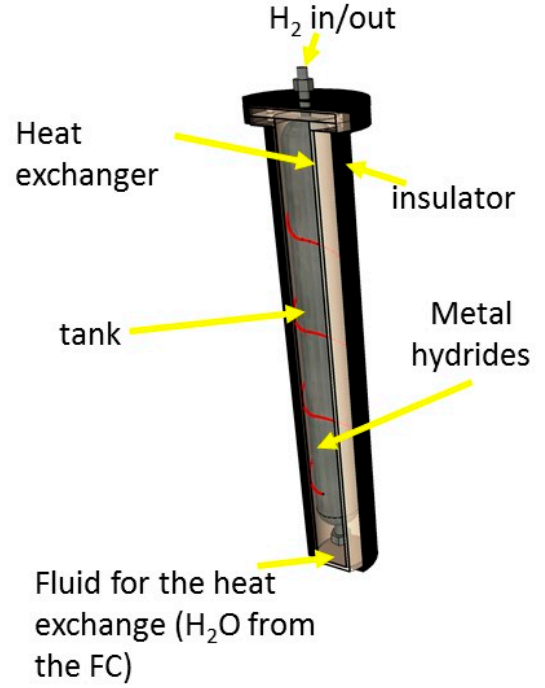

(a)

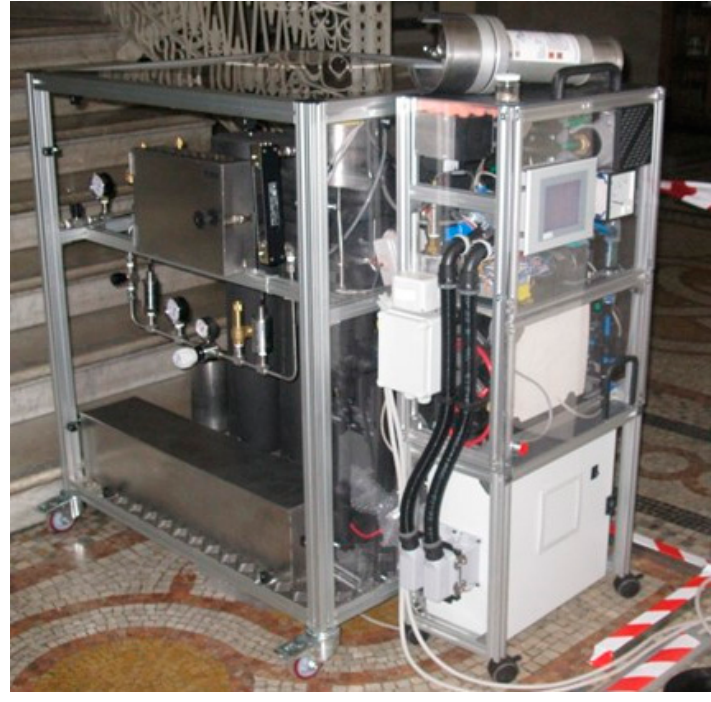

(b)

Figure 5. Stationary application of hydrogen storage using $\mathrm{LaNi}_{4.8} \mathrm{Al}_{0.2}$ as a carrier. (a) Schematic view of the hydrogen tank; (b) general view of the developed system. Details available in Rizzi et al. [142].

Mg-based systems are work at high temperatures (e.g., $360^{\circ} \mathrm{C}$ ) and $0.1 \mathrm{MPa}$. As an example, the McStore system from McPhy (France) is based on a standard configuration with 12 cylinders containing about $90 \mathrm{Nm}^{3}$ (i.e., $8 \mathrm{~kg}$ ) of $\mathrm{H}_{2}$. A demonstration was developed in the frame of the INGRID project, using about $750 \mathrm{~kg}$ of $\mathrm{H}_{2}$ carrier [156].

Complex hydrides are only available at the lab scale from mainstream chemical sellers. They have mainly been investigated at the lab scale, with a high purity grade, for research purposes. Application-oriented projects, however, have demonstrated their scale up. As an example, a scaled up system was built and tested by Johnson et al., storing $3 \mathrm{~kg}$ of hydrogen in modified $\mathrm{NaAlH}_{4}$ [157].

For on-board vehicular applications, sodium and lithium alanates are particularly effective, since they have high gravimetric capacities and they can release hydrogen at temperatures lower than $200^{\circ} \mathrm{C}$, ideal for coupling with HT-PEM FC. Within the SSH2S (fuel-cell-coupled solid-state hydrogen storage tank) project (2011-2015), a demonstration solid-state hydrogen tank was realized [158] to supply for $2 \mathrm{~h}$ a $1 \mathrm{~kW}$ HT-PEM FC stack as an auxiliary power unit (APU) for a light-duty vehicle. The optimized hydrogen storage material was synthetized by ball milling [159]. It was an amide-hydride composite containing $2 \mathrm{LiNH}_{2}-1.1 \mathrm{MgH}_{2}-0.1 \mathrm{LiBH}_{4}-3$ wt. $\% \mathrm{ZrCoH}_{3}$ coupled with $\mathrm{LaNi}_{4.3} \mathrm{Al}_{0.4} \mathrm{Mn}_{0.3}$, and it can release reversibly, at $150{ }^{\circ} \mathrm{C}, 4.5 \mathrm{wt} . \%$ of hydrogen in $300 \mathrm{~min}$ under $0.1 \mathrm{MPa}$, forming $\mathrm{Li}_{2} \mathrm{MgN}_{2} \mathrm{H}_{2}$, together with some residual $\mathrm{ZrCoH}_{3}$ [160-162]. The tank has a gravimetric hydrogen storage density of $2.45 \mathrm{wt} . \% \mathrm{H}_{2}$ (volumetric storage capacity of $\left.10 \mathrm{~g} \mathrm{~L}^{-1}\right)$, releasing hydrogen at $170{ }^{\circ} \mathrm{C}[162,163]$. An overview of the developed tank is reported in Figure 6. The storage tank consisted of three concentric tubes and the hydrogen carrier was based on a mixed lithium amide/magnesium hydride system, coupled with an intermetallic compound [162]. The system was planned to supply a $1 \mathrm{~kW}$ HT-PEM FC stack for $2 \mathrm{~h}$. The developed hydrogen tank is reported in Figure 6a. The complete storage system combined 12 vessels in parallel (Figure 6b), and a general view of the integrated APU system is reported in Figure 6c. 


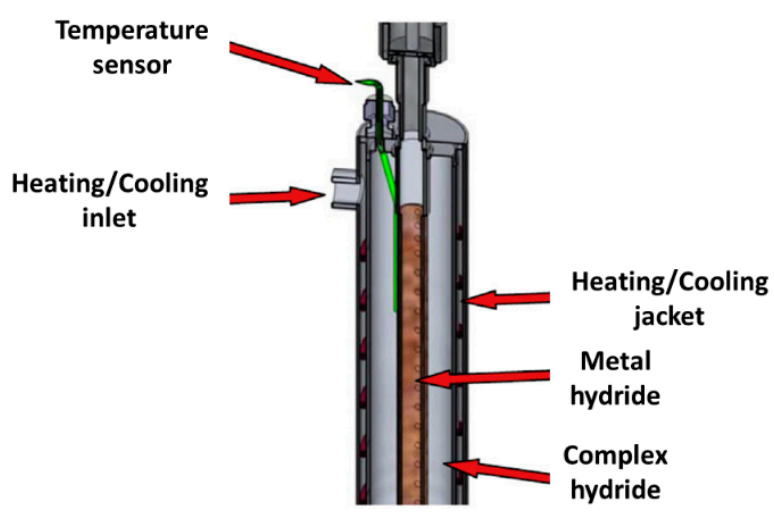

(a)

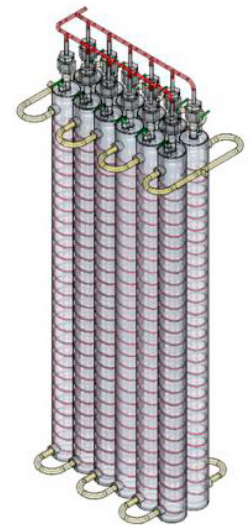

(b)

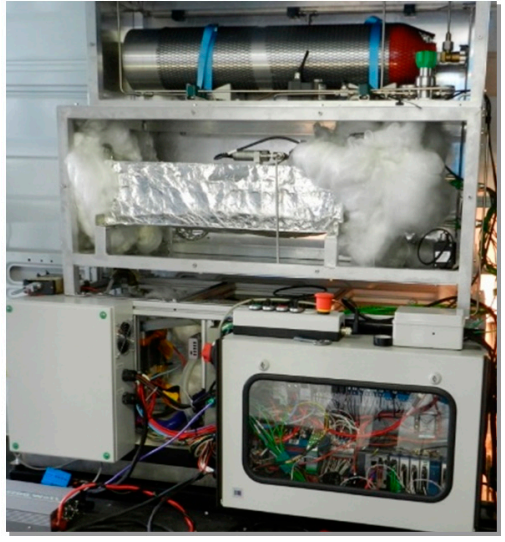

(c)

Figure 6. Solid-state hydrogen tank, coupled with a HT-PEM FC to be used as an auxiliary power unit (APU) using a complex hydride as carrier. (a) Scheme of single vessel implementing the double storage materials concept (combi-tank); (b) assembly of 12 vessels in parallel to form the complete storage system; (c) general view of the developed system. Details available in Baricco et al. [162].

The development of the tank was followed by a study involving a life-cycle assessment (LCA) [17], which demonstrated that, when the electricity consumption for hydrogen gas compression is included in the analysis, a solid-state hydrogen storage tank has similar greenhouse gas emissions and primary energy demand to those of type III and IV gas tanks [17].

\section{Discussion and Conclusions}

Metal hydrides allow storing $\mathrm{H}_{2}$ at low temperature (e.g., even close to room temperature) and at low pressure (e.g., $<50$ bar), being easily integrated with a low-pressure electrolyzer upstream and/or fuel cell downstream. A drawback is their low gravimetric capacity ( $<2 \mathrm{wt} . \%)$, which implies a higher amount of alloy compared to high-gravimetriccapacity hydrides, such as complex ones, to reach the same amount of $\mathrm{H}_{2}$ stored. Nevertheless, easier designs thanks to low-temperature and -pressure conditions are allowed, compared to complex hydrides, which usually require high temperatures. Intermetallic compounds are particularly interesting in stationary applications [108], in which there are no limitations on system weight, as well as in heavy mobile applications, such as forklifts [164] or submarines [133]. Lastly, concerning the volumetric capacity, it is on the order of $110 \mathrm{~kg} \mathrm{H}_{2} \cdot \mathrm{m}^{-3}$ (i.e., higher than liquid $\mathrm{H}_{2}$ ). The thermodynamic and kinetic properties of metal hydrides allow simple and suitable designs for solid-state hydrogen tanks. $\mathrm{AB}_{2}$ compounds have received high interest for mobility applications, but $\mathrm{AB}_{5}$-based systems are also under development. Hydrogen tanks based on solid-state materials are already available on the market, but limited applications have been demonstrated. Because of the main properties of the hydrogen carriers (i.e., gravimetric and volumetric $\mathrm{H}_{2}$ density), large weights and volumes must be considered for the tank system if the request for stored hydrogen is high. The limited market strongly limits the availability and increases the cost of metal powders for hydrogen storage.

Hydrides can provide a technically suitable solution for the storage of renewable energies and, therefore, can play a relevant role in fostering the transition toward an energy system characterized by a wide adoption of renewable technologies. However, it is now recognized, both in the research and in the policy fields, that technical aspects are only part of the solutions and the social aspects have been gaining relevance in the past decades as crucial components for investigating the transition pathways (e.g., the long-lasting sociotechnical transition approach) $[11,24,26]$ and for designing effective policies for their implementation. 
In order to estimate possible applications of solid-state hydrogen storage for energy communities, different scenarios have been considered. As a starting point, the green hydrogen production of $1 \mathrm{~kg}$ of hydrogen by water electrolysis is taken as a reference, considering an energy consumption for hydrogen production of $50 \mathrm{kWh} / \mathrm{kg} \mathrm{H}_{2}$, so that the time for production can be estimated as a function of the power of an alakaline electrolyzer. Results are reported in Figure 7a, and they show a significant decrease in production time up to about $6 \mathrm{~kW}$, which allows the production of $3 \mathrm{~kg} \mathrm{H}_{2}$ per day. Similarly, the running time of a PEM FC with $1 \mathrm{~kg}$ of $\mathrm{H}_{2}$ can be estimated as a function of power, as reported in Figure $7 \mathrm{~b}$. In this case, a hydrogen consumption of $0.075 \mathrm{~kg} \mathrm{H}_{2}$ per electric $\mathrm{kWh}$ is considered, which implies an FC efficiency of about $50 \%$. It turns out that, with a $3 \mathrm{~kW}$ PEM FC, a one day running time would be possible with about $3 \mathrm{~kg} \mathrm{H}_{2}$.
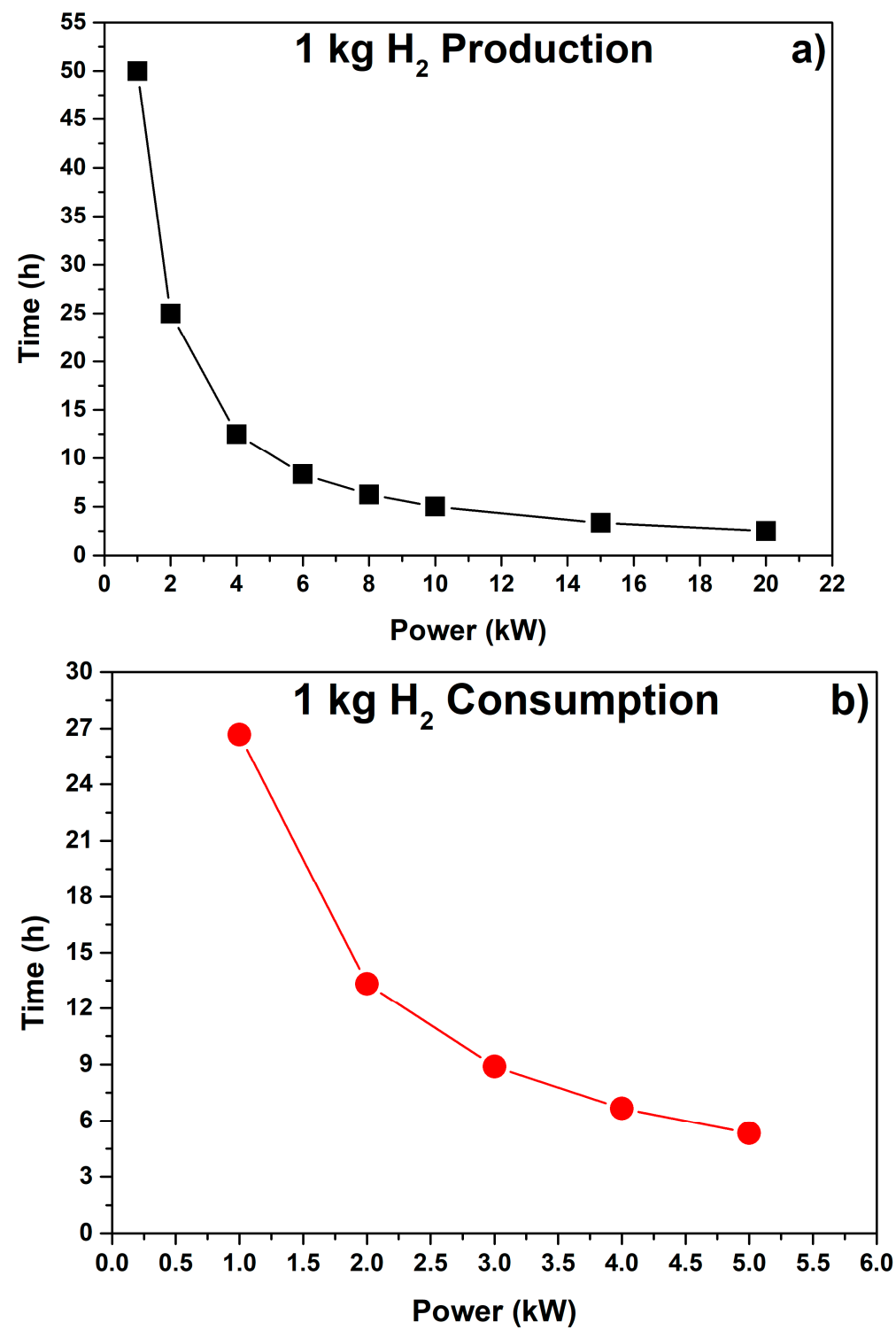

Figure 7. Time for (a) production by an electrolyzer and (b) consumption by a fuel cell of $1 \mathrm{~kg} \mathrm{H}_{2}$ as a function of power of the equipment.

In order to estimate a possible supply for energy communities, electric consumptions obtained in 2018 were considered [1] and days per capita of electric supply are reported as a function of the amount of hydrogen available (Figure 8). 


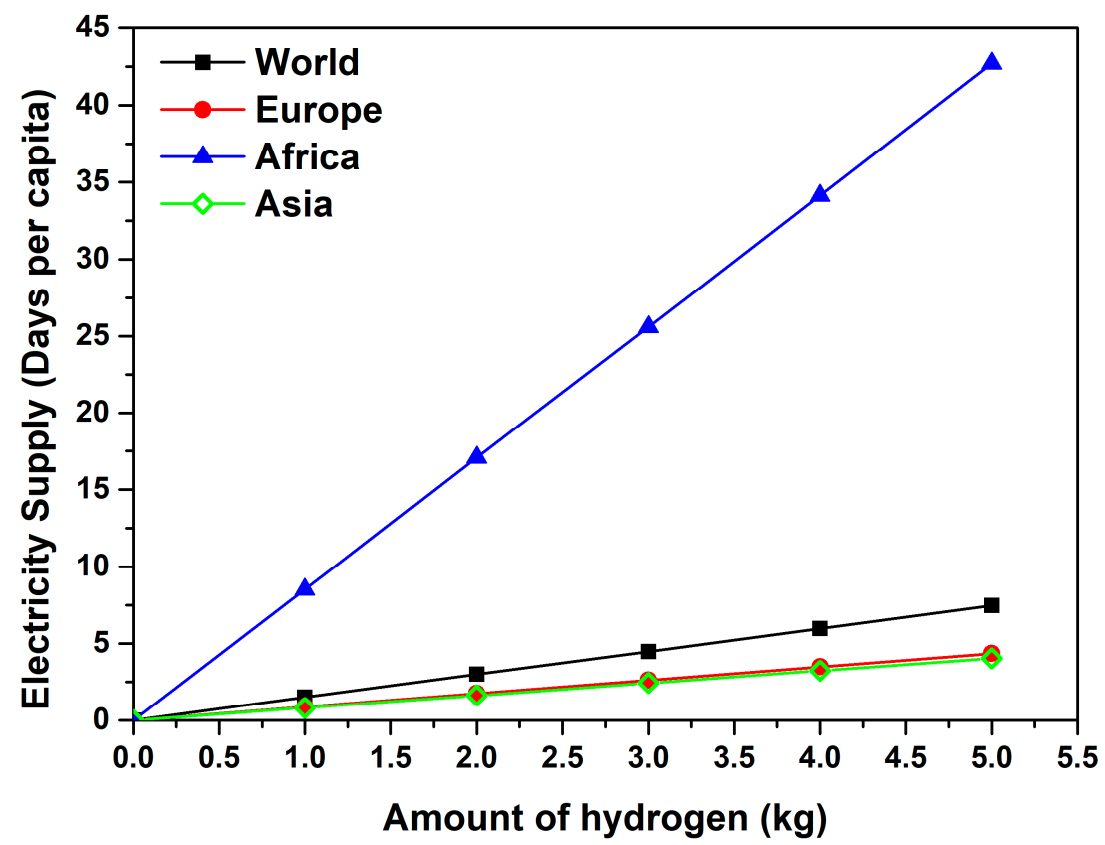

Figure 8. Days of electric supply per capita as a function of the amount of hydrogen available, considering different social environments.

It turns out that, with $5 \mathrm{~kg}$ of $\mathrm{H}_{2}$ available, a family of four persons can be fully supplied for 1 day in Europe and Asia, whereas the same amount of hydrogen can today supply the same family in Africa for about 10 days. If a usable amount of $1.3 \mathrm{wt} . \%$ in the temperature and pressure ranges of the metal hydride storage system is considered, the storage of $5 \mathrm{~kg} \mathrm{H}_{2}$ would need about $385 \mathrm{~kg}$ of powder. This would occupy only $0.071 \mathrm{~m}^{3}$ with a metal hydride showing a volumetric density of $100 \mathrm{~kg} \mathrm{H}_{2} / \mathrm{m}^{3}$, considering a bulk-to-powder ratio of 0.7 . Of course, the real volume of the system would increase due to the need of a piping, valves, and thermal management. Lastly, considering a price of $50 \mathrm{EUR} / \mathrm{kg}$ for the selected powder, a total cost of less than 20,000 EUR would be necessary for the active materials, which would increase because of auxiliaries. A scaleup of the storage of renewable energies by hydrogen using metal hydrides would benefit significantly from the cost reduction due to the increased quantity of powder, maintaining a reduced footprint of the system, coupled with safe conditions, linked to the low pressure and temperature involved in the technology. Hydrogen technologies, especially for the stationary storage of energy, can be coupled with renewable sources to produce and store green energy, thus allowing for a crucial step toward overcoming the discontinuity in the provision of electricity from RES.

For a technical innovation to be properly developed and diffused and to be adequately accepted and adopted by the users (ultimately, the citizens), attention must be paid to the social, economic, and cultural context within which the innovation should be embedded, to better design the innovation itself, to minimize the negative impacts, and to maximize the potential benefits. Among the many social aspects and dynamics that deserve to be considered, the promotion of a gender perspective as a driver for more innovative and inclusive solutions in the clean energy transition and in the hydrogen-based solution exploitation must be implemented. This innovation might also represent a huge shift for encouraging local communities and families to become prosumers and could also be leverage for making the energy transition an opportunity for the enhancement of women's conditions.

A recent study on prosumers' energy practice in households in Norway and the United Kingdom in fact evidenced that the introduction of energy production and use influences everyday routines and lifestyle [165]. The implementation of a storage system based on hydrogen within an integrated energy system enables new organization of in-house tasks due to the improved control over the distribution of smart energy use. $\mathrm{H}_{2}$-based storage solutions 
might, therefore, positively impact the condition of women, to date still the most responsible for managing chores at home. On one hand, these solutions might increase women's free time and their autonomy in managing the daily scheduling, and they might trigger the shift to a more gender-balanced distribution of chores in an ungendered house space.

From the gender perspective, the dark side of $\mathrm{H}_{2}$ development, as reported by the study in [165], is the role of males in the decision and adoption of renewable energy systems and their maintenance. This process, today, is still skewed toward men due to the requirement of more technical skills and, as a result of a historical but still persistent trend, is characterized by a highly unbalanced distribution of STEM competencies [165]. Given this evidence, the goal must be to increase women's involvement in the process as bearers of expert knowledge, thereby steering the decision-making process. The development of $\mathrm{H}_{2}$-based technologies might help in fulfilling these goals through two main strategies. Firstly, women's present STEM skills that are relevant for $\mathrm{H}_{2}$-based solutions can be collected, as fostered by the "Women in Green Hydrogen" network, which created an expert database of passionate women working in the green hydrogen sector [166]. Their vision is to increase the visibility and amplify the voices of women working in green hydrogen. More than other RES technologies, $\mathrm{H}_{2}$-based ones need technical engineering skills to be complemented by other knowledge (e.g., chemistry and physics) where the female component is relatively more represented. Secondly, in the mid-term, the inclusion of STEM women in $\mathrm{H}_{2}$ development might play a driving role in steering women's educational and professional careers toward the STEM fields.

In conclusion, $\mathrm{H}_{2}$ might positively impact women both as a trigger for a more balanced distribution of daily activities connected to family and house management and as a trigger for enhancing the role of women in the decision process toward the adoption of $\mathrm{H}_{2}$ solutions through the enhancement of their STEM skills.

The implementation of a storage system based on hydrogen within an integrated energy system would enable new organizational in-house tasks, leaving more freedom in the use of smart energy and empowering women in implementing their free time and developing an ungendered house space toward a balanced division of household tasks and maintenance. Furthermore, climate change impact will differently affect the north and the south of the world, and the vulnerability of women during the energy transition should be considered to protect these populations and supporting the unique values and virtues of women, to locally foster the energy transition and to lead toward increased women's responsibility and communication roles in the energy market [29].

Given their role in the organization of social life and in fostering innovative solutions, both in developing and developed countries, albeit through different mechanisms, women's inclusion in the development of hydrogen-related technologies will provide a more comprehensive view with regard to the exploitation of its storage potential in the overall reorganization of the daily and working life, thus possibly triggering an actual empowerment of women through an increase in their talent and skills (i.e., share in STEM) and their involvement in the energy chain decision making. The transition toward renewable energies, from their production to their use, seems to be a unique opportunity to foster women's empowerment; furthermore, involving women might aid in fostering the transition process itself. Engendered energy policy might create enabling conditions and opportunities for energy transition in general and, at a lower scale, might facilitate project design and implementation [26]. Through the adoption of a sociotechnical approach, we propose explaining this potential of women in the energy transition and renewable-based technology adoption (such as for solid-state hydrogen storage systems) on the basis of the social innovation that they are able to trigger at the niche, regime and wider landscape levels. They can play a crucial role in triggering innovation in daily life (as explorers of new solutions), in the management of social life and (public and private) organizations, and in promoting the renovation of the cultural, political, and, in the long run, institutional frameworks (women as carriers of new values). Although a large body of scientific and gray literature, in addition to the policy plans at different governmental levels, allows 
supporting this general framework, an application to the specific context of solid-state hydrogen storage systems needs to be validated through the collection of primary data for a full comprehension of the dynamics that might support the exploitation of women's potential for hydrogen development. Primary data, given the niche level of the current development of solid-state hydrogen storage systems, can only be built through careful case studies, which could provide evidence of women's role at the micro level of the individual/household adoption of hydrogen-based solutions and at the meso level of their involvement in defining strategies for innovation in public and private organizations.

Author Contributions: P.R. and E.M.D. are responsible for the ideation; E.M.D., J.B., M.C., A.S. and M.B. performed the literature search and data analysis, E.M.D., J.B., M.C., A.S., M.B. and P.R. drafted and revised the work. All authors have read and agreed to the published version of the manuscript.

Funding: The project leading to this publication received funding from the Fuel Cells and Hydrogen 2 Joint Undertaking (JU) under grant agreement No. 826352, HyCARE project. The JU receives support from the European Union's Horizon 2020 research, Hydrogen Europe, and Hydrogen Europe Research innovation programs, as well as from Italy, France, Germany, and Norway, which are all thankfully acknowledged.

Institutional Review Board Statement: Not applicable.

Informed Consent Statement: Not applicable.

Data Availability Statement: Data sharing not applicable. No new data were created or analyzed in this study. Data sharing is not applicable to this article.

Conflicts of Interest: The authors declare no conflict of interest.

\section{References}

1. IEA. Data and Statistics. Available online: https://www.iea.org/data-and-statistics (accessed on 1 February 2021).

2. IEA. Change in Electricity Demand in 2020 and 2021 by Region. Available online: https://www.iea.org/data-and-statistics/ charts / change-in-electricity-demand-in-2020-and-2021-by-region (accessed on 1 February 2021).

3. IEA. Global Energy Review 2021-CO2 Emissions. Available online: https://www.iea.org/reports/global-energy-review-2021 / co2-emissions (accessed on 1 February 2021).

4. IEA. Documentation for Electricity Information 2020. Available online: https://iea.blob.core.windows.net/assets/e5ee2901-20 4b-4977-8d6c-91b97e69dd94/Ele_documentation.pdf. (accessed on 1 February 2021).

5. Paris Agreement-Report of the Conference of the Parties on Its Twenty-First Session; FCCC/CP/2015/10/Add.1; United Nations, European Commision Secretariate: New York, NY, USA, 2015.

6. European Commision. Clean Energy for All Europeans-European Commission, Directorate General for Energy; European Commision: Brussels, Belgium, 2019. [CrossRef]

7. Armaroli, N.; Balzani, V. The Future of Energy Supply: Challenges and Opportunities. Angew. Chemie Int. Ed. 2007, 46, 52-66. [CrossRef]

8. Rehman, S.; Al-Hadhrami, L.M.; Alam, M.M. Pumped hydro energy storage system: A technological review. Renew. Sustain. Energy Rev. 2015, 44, 586-598. [CrossRef]

9. Trist, E.L. A conceptual framework and action research program. In The Evolution of Socio-Technical Systems; Ontario Quality of Working Life Centre: Toronto, ON, Canada, 1981.

10. Walker, G.; Cass, N. Carbon reduction, 'the public' and renewable energy: Engaging with socio-technical configurations. Area 2007, 39, 458-469. [CrossRef]

11. Geels, F.W.; Schot, J. Typology of sociotechnical transition pathways. Res. Policy 2007, 36, 399-417. [CrossRef]

12. Smith, A.; Stirling, A.; Berkhout, F. The governance of sustainable socio-technical transitions. Res. Policy 2005, 34, 1491-1510. [CrossRef]

13. Møller, K.T.; Jensen, T.R.; Akiba, E.; Li, H.-W. Hydrogen-A sustainable energy carrier. Prog. Nat. Sci. Mater. Int. 2017, 27, 34-40. [CrossRef]

14. Armaroli, N.; Balzani, V. The Hydrogen Issue. ChemSusChem 2011, 4, 21-36. [CrossRef]

15. Lai, Q.; Paskevicius, M.; Sheppard, D.A.; Buckley, C.E.; Thornton, A.W.; Hill, M.R.; Gu, Q.; Mao, J.; Huang, Z.; Liu, H.K.; et al. Hydrogen Storage Materials for Mobile and Stationary Applications: Current State of the Art. ChemSusChem 2015, 8, 2789-2825. [CrossRef]

16. Ball, M.; Wietschel, M. The future of hydrogen—opportunities and challenges. Int. J. Hydrogen Energy 2009, 34, 615-627. [CrossRef]

17. Agostini, A.; Belmonte, N.; Masala, A.; Hu, J.; Rizzi, P.; Fichtner, M.; Moretto, P.; Luetto, C.; Sgroi, M.; Baricco, M. Role of hydrogen tanks in the life cycle assessment of fuel cell-based auxiliary power units. Appl. Energy 2018, 215, 1-12. [CrossRef]

18. Belmonte, N.; Girgenti, V.; Florian, P.; Peano, C.; Luetto, C.; Rizzi, P.; Baricco, M. A comparison of energy storage from renewable sources through batteries and fuel cells: A case study in Turin, Italy. Int. J. Hydrogen Energy 2016, 41, 21427-21438. [CrossRef]

19. Wierling, A.; Zeiss, J.P.; Lupi, V.; Candelise, C.; Sciullo, A.; Schwanitz, V.J. The Contribution of Energy Communities to the Upscaling of Photovoltaics in Germany and Italy. Energies 2021, 14, 2258. [CrossRef] 
20. Directive (EU) 2019/944 on common rules for the internal market for electricity. Off. J. Eur. Union 2019, L158, 125-199.

21. Directive (EU) 2018/2001 on the promotion of the use of energy from renewable sources. Off. J. Eur. Union 2018, L328, 82-209.

22. COP24 Women Gender Constituency-Key Demands 2021. Available online: www.womengenderclimate.org (accessed on 15 January 2021).

23. Feenstra, M.; Özerol, G. Energy justice as a search light for gender-energy nexus: Towards a conceptual framework. Renew. Sustain. Energy Rev. 2021, 138, 110668. [CrossRef]

24. Geels, F.W. Socio-technical transitions to sustainability: A review of criticisms and elaborations of the Multi-Level Perspective. Curr. Opin. Environ. Sustain. 2019, 39, 187-201. [CrossRef]

25. Verbong, G.P.J.; Geels, F.W. Exploring sustainability transitions in the electricity sector with socio-technical pathways. Technol. Forecast. Soc. Change 2010, 77, 1214-1221. [CrossRef]

26. Geels, F.W. Technological transitions as evolutionary reconfiguration processes: A multi-level perspective and a case-study. Res. Policy 2002, 31, 1257-1274. [CrossRef]

27. Hopkins, M. Human development revisited: A new UNDP report. World Dev. 1991, 19, 1469-1473. [CrossRef]

28. Gender and Climate Change-Thematic Issue Briefs and Training Modules. Available online: http://www.undp.org/content/ undp/en/home/librarypage/womens-empowerment/gender-and-climate-change.html (accessed on 7 July 2018).

29. Arora-Jonsson, S. Virtue and vulnerability: Discourses on women, gender and climate change. Glob. Environ. Chang. 2011, 21, 744-751. [CrossRef]

30. Lieu, J.; Sorman, A.H.; Johnson, O.W.; Virla, L.D.; Resurrección, B.P. Three sides to every story: Gender perspectives in energy transition pathways in Canada, Kenya and Spain. Energy Res. Soc. Sci. 2020, 68, 101550. [CrossRef]

31. Wong, S. Can Climate Finance Contribute to Gender Equity in Developing Countries? J. Int. Dev. 2016, 28, 428-444. [CrossRef]

32. Shankar, A. Strategically Engaging Women in Clean Energy Solutions for Sustainable Development and Health. In Global Sustainable Development Report; United Nations, Department of Economic and Social Affairs: New York, NY, USA, July 2015.

33. Carlsson-Kanyama, A.; Lindén, A.-L. Energy efficiency in residences-Challenges for women and men in the North. Energy Policy 2007, 35, 2163-2172. [CrossRef]

34. International Renewable Energy Agency. Renewable Energy: A Gender Perspective; International Renewable Energy Agency: Masdar City, United Arab Emirates, 2019; ISBN 9789292600983.

35. Sartori, S. Further Steps Are Needed to Endure a Gender-Just Energy Transition; FES: Bonn, Germany, 2020.

36. Loarne-Lemaire, S.L.; Bertrand, G.; Razgallah, M.; Maalaoui, A.; Kallmuenzer, A. Women in innovation processes as a solution to climate change: A systematic literature review and an agenda for future research. Technol. Forecast. Soc. Chang. 2021, 164, 120440. [CrossRef]

37. Cannon, C.E.B.; Chu, E.K. Gender, sexuality, and feminist critiques in energy research: A review and call for transversal thinking. Energy Res. Soc. Sci. 2021, 75, 102005. [CrossRef]

38. Mang-Benza, C. Many shades of pink in the energy transition: Seeing women in energy extraction, production, distribution, and consumption. Energy Res. Soc. Sci. 2021, 73, 101901. [CrossRef]

39. Allen, E.; Lyons, H.; Stephens, J.C. Women's leadership in renewable transformation, energy justice and energy democracy: Redistributing power. Energy Res. Soc. Sci. 2019, 57, 101233. [CrossRef]

40. Hirscher, M.; Yartys, V.A.; Baricco, M.; Bellosta von Colbe, J.; Blanchard, D.; Bowman, R.C.; Broom, D.P.; Buckley, C.E.; Chang, F.; Chen, P.; et al. Materials for hydrogen-based energy storage-past, recent progress and future outlook. J. Alloys Compd. 2020, 827, 153548. [CrossRef]

41. Szilágyi, P.Á.; Rogers, D.M.; Zaiser, I.; Callini, E.; Turner, S.; Borgschulte, A.; Züttel, A.; Geerlings, H.; Hirscher, M.; Dam, B. Functionalised metal-organic frameworks: A novel approach to stabilising single metal atoms. J. Mater. Chem. A 2017, 5, 15559-15566. [CrossRef]

42. Liu, W.; Setijadi, E.; Crema, L.; Bartali, R.; Laidani, N.; Aguey-Zinsou, K.F.; Speranza, G. Carbon nanostructures/Mg hybrid materials for hydrogen storage. Diam. Relat. Mater. 2018, 82, 19-24. [CrossRef]

43. Zavorotynska, O.; Deledda, S.; Vitillo, J.; Saldan, I.; Guzik, M.; Baricco, M.; Walmsley, J.; Muller, J.; Hauback, B. Combined X-ray and Raman Studies on the Effect of Cobalt Additives on the Decomposition of Magnesium Borohydride. Energies 2015, 8, 9173-9190. [CrossRef]

44. Broom, D.P.; Webb, C.J.; Fanourgakis, G.S.; Froudakis, G.E.; Trikalitis, P.N.; Hirscher, M. Concepts for improving hydrogen storage in nanoporous materials. Int. J. Hydrogen Energy 2019, 44, 7768-7779. [CrossRef]

45. Hirscher, M. Handbook of Hydrogen Storage: New Materials for Future Energy Storage; Wiley: Hoboken, NJ, USA, 2010; ISBN 9783527320813.

46. Callini, E.; Aguey-Zinsou, K.-F.; Ahuja, R.; Ares, J.R.; Bals, S.; Biliškov, N.; Chakraborty, S.; Charalambopoulou, G.; Chaudhary, A.-L.; Cuevas, F.; et al. Nanostructured materials for solid-state hydrogen storage: A review of the achievement of COST Action MP1103. Int. J. Hydrogen Energy 2016, 41, 14404-14428. [CrossRef]

47. Schlichtenmayer, M.; Hirscher, M. The usable capacity of porous materials for hydrogen storage. Appl. Phys. A 2016, 122, 379. [CrossRef]

48. Broom, D.P.; Webb, C.J.; Hurst, K.E.; Parilla, P.A.; Gennett, T.; Brown, C.M.; Zacharia, R.; Tylianakis, E.; Klontzas, E.; Froudakis, G.E.; et al. Outlook and challenges for hydrogen storage in nanoporous materials. Appl. Phys. A 2016, 122, 151. [CrossRef]

49. Gaboardi, M.; Milanese, C.; Magnani, G.; Girella, A.; Pontiroli, D.; Cofrancesco, P.; Marini, A.; Riccò, M. Optimal hydrogen storage in sodium substituted lithium fullerides. Phys. Chem. Chem. Phys. 2017, 19, 21980-21986. [CrossRef] 
50. Pramudita, J.C.; Pontiroli, D.; Magnani, G.; Gaboardi, M.; Milanese, C.; Bertoni, G.; Sharma, N.; Riccò, M. Effect of Ni-nanoparticles decoration on graphene to enable high capacity sodium-ion battery negative electrodes. Electrochim. Acta 2017, 250, 212-218. [CrossRef]

51. Sarzi Amadè, N.; Gaboardi, M.; Magnani, G.; Riccò, M.; Pontiroli, D.; Milanese, C.; Girella, A.; Carretta, P.; Sanna, S. H and Li dynamics in Li12C60 and Li12C60Hy. Int. J. Hydrogen Energy 2017, 42, 22544-22550. [CrossRef]

52. El Kharbachi, A.; Dematteis, E.M.; Shinzato, K.; Stevenson, S.C.; Bannenberg, L.J.; Heere, M.; Zlotea, C.; Szilágyi, P.Á.; Bonnet, J.-P.; Grochala, W.; et al. Metal Hydrides and Related Materials. Energy Carriers for Novel Hydrogen and Electrochemical Storage. J. Phys. Chem. C 2020, 124, 7599-7607. [CrossRef]

53. Bannenberg, L.J.; Heere, M.; Benzidi, H.; Montero, J.; Dematteis, E.M.; Suwarno, S.; Jaron, T.; Winny, M.; Orłowski, P.A.; Wegner, W.; et al. Metal (boro-) hydrides for high energy density storage and relevant emerging technologies. Int. J. Hydrogen Energy 2020, 45, 33687-33730. [CrossRef]

54. Weidenthaler, C. Crystal structure evolution of complex metal aluminum hydrides upon hydrogen release. J. Energy Chem. 2020, 42, 133-143. [CrossRef]

55. Hadjixenophontos, E.; Dematteis, E.M.; Berti, N.; Wołczyk, A.R.; Huen, P.; Brighi, M.; Le, T.T.; Santoru, A.; Payandeh, S.; Peru, F.; et al. A Review of the MSCA ITN ECOSTORE-Novel Complex Metal Hydrides for Efficient and Compact Storage of Renewable Energy as Hydrogen and Electricity. Inorganics 2020, 8, 17. [CrossRef]

56. Yartys, V.A.; Lototskyy, M.V.; Akiba, E.; Albert, R.; Antonov, V.E.; Ares, J.R.; Baricco, M.; Bourgeois, N.; Buckley, C.E.; Bellosta von Colbe, J.M.; et al. Magnesium based materials for hydrogen based energy storage: Past, present and future. Int. J. Hydrogen Energy 2019, 44, 7809-7859. [CrossRef]

57. Crivello, J.-C.; Denys, R.V.; Dornheim, M.; Felderhoff, M.; Grant, D.M.; Huot, J.; Jensen, T.R.; de Jongh, P.; Latroche, M.; Walker, G.S.; et al. Mg-based compounds for hydrogen and energy storage. Appl. Phys. A 2016, 122, 85. [CrossRef]

58. Joubert, J.-M.; Paul-Boncour, V.; Cuevas, F.; Zhang, J.; Latroche, M. LaNi5 related AB5 compounds: Structure, properties and applications. J. Alloys Compd. 2021, 862, 158163. [CrossRef]

59. Dornheim, M. Thermodynamics of Metal Hydrides: Tailoring Reaction Enthalpies of Hydrogen Storage Materials. In Thermodynamics—Interaction Studies—Solids, Liquids and Gases; InTech: London, UK, 2011; pp. 891-918. ISBN 978-953-307-563-1.

60. Baran, A.; Polański, M. Magnesium-Based Materials for Hydrogen Storage-A Scope Review. Materials 2020, 13, 3993. [CrossRef]

61. Graetz, J.; Reilly, J.J.; Yartys, V.A.; Maehlen, J.P.; Bulychev, B.M.; Antonov, V.E.; Tarasov, B.P.; Gabis, I.E. Aluminum hydride as a hydrogen and energy storage material: Past, present and future. J. Alloys Compd. 2011, 509, S517-S528. [CrossRef]

62. Léon, A. (Ed.) Hydrogen Technology. In Green Energy and Technology; Springer: Berlin/Heidelberg, Germany, 2008; ISBN 978-3-540-79027-3.

63. Dematteis, E.M.; Berti, N.; Cuevas, F.; Latroche, M.; Baricco, M. Substitutional effects in TiFe for hydrogen storage: A comprehensive review. Mater. Adv. 2021, 2, 2524-2560. [CrossRef]

64. Sujan, G.K.; Pan, Z.; Li, H.; Liang, D.; Alam, N. An overview on TiFe intermetallic for solid-state hydrogen storage: Microstructure, hydrogenation and fabrication processes. Crit. Rev. Solid State Mater. Sci. 2019, 45, 410-427. [CrossRef]

65. Reilly, J.J.; Wiswall, R.H. Formation and properties of iron titanium hydride. Inorg. Chem. 1974, 13, 218-222. [CrossRef]

66. Dematteis, E.M.; Dreistadt, D.M.; Capurso, G.; Jepsen, J.; Cuevas, F.; Latroche, M. Fundamental hydrogen storage properties of TiFe-alloy with partial substitution of Fe by Ti and Mn. J. Alloys Compd. 2021, 874, 159925. [CrossRef]

67. Dematteis, E.M.; Cuevas, F.; Latroche, M. Hydrogen storage properties of Mn and Cu for Fe substitution in TiFe0.9 intermetallic compound. J. Alloys Compd. 2021, 851, 156075. [CrossRef]

68. Rusman, N.A.A.; Dahari, M. A review on the current progress of metal hydrides material for solid-state hydrogen storage applications. Int. J. Hydrogen Energy 2016, 41, 12108-12126. [CrossRef]

69. Stein, F.; Palm, M.; Sauthoff, G. Structure and stability of Laves phases. Part I. Critical assessment of factors controlling Laves phase stability. Intermetallics 2004, 12, 713-720. [CrossRef]

70. Liu, B.-H.; Kim, D.-M.; Lee, K.-Y.; Lee, J.-Y. Hydrogen storage properties of TiMn2-based alloys. J. Alloys Compd. 1996, 240, 214-218. [CrossRef]

71. Lototskyy, M.V.; Tolj, I.; Pickering, L.; Sita, C.; Barbir, F.; Yartys, V. The use of metal hydrides in fuel cell applications. Prog. Nat. Sci. Mater. Int. 2017, 27, 3-20. [CrossRef]

72. Commission's communication on the 2017 list of Critical raw Materials for the EU. COM 2017, 490. Available online: https: / / ec.europa.eu/transparency/documents-register/detail?ref=COM(2017)490\&lang=en (accessed on 1 February 2021).

73. EU Critical Raw Materials Resilience: Charting a Path towards greater Security and Sustainability. Communication from the commission to the European parliament, the council, the European Economic and Social Committee and the committee of the regions. COM 2020, 474. Available online: https://op.europa.eu/en/publication-detail/-/publication/160da878-edc7-11ea-99 1b-01aa75ed71a1/language-en (accessed on 1 February 2021).

74. Liang, G.; Huot, J.; Schulz, R. Hydrogen storage properties of the mechanically alloyed LaNi5-based materials. J. Alloys Compd. 2001, 320, 133-139. [CrossRef]

75. Read, C.; Petrovic, J.; Ordaz, G.; Satyapal, S. The DOE National Hydrogen Storage Project: Recent Progress in On-Board Vehicular Hydrogen Storage. MRS Proc. 2005, 885, 501. [CrossRef]

76. An, X.H.; Gu, Q.F.; Zhang, J.Y.; Chen, S.L.; Yu, X.B.; Li, Q. Experimental investigation and thermodynamic reassessment of La-Ni and LaNi5-H systems. Calphad 2013, 40, 48-55. [CrossRef]

77. Chen, J.; Dou, S.X.; Liu, H.K. Effect of partial substitution of La with Ce, Pr and Nd on the properties of LaNi5-based alloy electrodes. J. Power Source 1996, 63, 267-270. [CrossRef] 
78. Milanese, C.; Jensen, T.R.; Hauback, B.C.; Pistidda, C.; Dornheim, M.; Yang, H.; Lombardo, L.; Zuettel, A.; Filinchuk, Y.; Ngene, P.; et al. Complex hydrides for energy storage. Int. J. Hydrogen Energy 2019, 44, 7860-7874. [CrossRef]

79. Milanese, C.; Garroni, S.; Gennari, F.; Marini, A.; Klassen, T.; Dornheim, M.; Pistidda, C. Solid State Hydrogen Storage in Alanates and Alanate-Based Compounds: A Review. Metals 2018, 8, 567. [CrossRef]

80. Sandrock, G.; Gross, K.; Thomas, G.; Jensen, C.; Meeker, D.; Takara, S. Engineering considerations in the use of catalyzed sodium alanates for hydrogen storage. J. Alloys Compd. 2002, 330-332, 696-701. [CrossRef]

81. Gross, K.J.; Thomas, G.J.; Jensen, C.M. Catalyzed alanates for hydrogen storage. J. Alloys Compd. 2002, 330-332, 683-690. [CrossRef]

82. Liu, Y.; Ren, Z.; Zhang, X.; Jian, N.; Yang, Y.; Gao, M.; Pan, H. Development of Catalyst-Enhanced Sodium Alanate as an Advanced Hydrogen-Storage Material for Mobile Applications. Energy Technol. 2018, 6, 487-500. [CrossRef]

83. Bogdanović, B.; Brand, R.A.; Marjanović, A.; Schwickardi, M.; Tölle, J. Metal-doped sodium aluminium hydrides as potential new hydrogen storage materials. J. Alloys Compd. 2000, 302, 36-58. [CrossRef]

84. Paskevicius, M.; Jepsen, L.H.; Schouwink, P.; Černý, R.; Ravnsbæk, D.B.; Filinchuk, Y.; Dornheim, M.; Besenbacher, F.; Jensen, T.R. Metal borohydrides and derivatives—synthesis, structure and properties. Chem. Soc. Rev. 2017, 46, 1565-1634. [CrossRef]

85. Puszkiel, J.; Garroni, S.; Milanese, C.; Gennari, F.; Klassen, T.; Dornheim, M.; Pistidda, C. Tetrahydroborates: Development and Potential as Hydrogen Storage Medium. Inorganics 2017, 5, 74. [CrossRef]

86. Rude, L.H.; Nielsen, T.K.; Ravnsbaek, D.B.; Bösenberg, U.; Ley, M.B.; Richter, B.; Arnbjerg, L.M.; Dornheim, M.; Filinchuk, Y.; Besenbacher, F.; et al. Tailoring properties of borohydrides for hydrogen storage: A review. Phys. Status Solidi 2011, 208, 1754-1773. [CrossRef]

87. Dematteis, E.M.; Jensen, S.R.; Jensen, T.R.; Baricco, M. Heat capacity and thermodynamic properties of alkali and alkali-earth borohydrides. J. Chem. Thermodyn. 2020, 143, 106055. [CrossRef]

88. Dematteis, E.M.; Roedern, E.; Pinatel, E.R.; Corno, M.; Jensen, T.R.; Baricco, M. A thermodynamic investigation of the LiBH4NaBH4 system. RSC Adv. 2016, 6, 60101-60108. [CrossRef]

89. Dematteis, E.M.; Pinatel, E.R.; Corno, M.; Jensen, T.R.; Baricco, M. Phase diagrams of the LiBH4-NaBH4-KBH4 system. Phys. Chem. Chem. Phys. 2017, 19, 25071-25079. [CrossRef]

90. Dematteis, E.M.; Pistidda, C.; Dornheim, M.; Baricco, M. Exploring Ternary and Quaternary Mixtures in the LiBH4-NaBH4KBH4-Mg(BH4)2-Ca(BH4)2 System. ChemPhysChem 2019, 20, 1348-1359. [CrossRef]

91. Dematteis, E.M.; Santoru, A.; Poletti, M.G.; Pistidda, C.; Klassen, T.; Dornheim, M.; Baricco, M. Phase stability and hydrogen desorption in a quinary equimolar mixture of light-metals borohydrides. Int. J. Hydrogen Energy 2018, 43, 16793-16803. [CrossRef]

92. Dematteis, E.M.; Vaunois, S.; Pistidda, C.; Dornheim, M.; Baricco, M. Reactive Hydride Composite of Mg2NiH4 with Borohydrides Eutectic Mixtures. Crystals 2018, 8, 90. [CrossRef]

93. Dematteis, E.M.; Baricco, M. Hydrogen Desorption in Mg(BH4)2-Ca(BH4)2 System. Energies 2019, 12, 3230. [CrossRef]

94. Garroni, S.; Santoru, A.; Cao, H.; Dornheim, M.; Klassen, T.; Milanese, C.; Gennari, F.; Pistidda, C. Recent Progress and New Perspectives on Metal Amide and Imide Systems for Solid-State Hydrogen Storage. Energies 2018, 11, 1027. [CrossRef]

95. Gulino, V.; Brighi, M.; Dematteis, E.M.; Murgia, F.; Nervi, C.; Černý, R.; Baricco, M. Phase Stability and Fast Ion Conductivity in the Hexagonal LiBH4-LiBr-LiCl Solid Solution. Chem. Mater. 2019, 31, 5133-5144. [CrossRef]

96. Gulino, V.; Dematteis, E.M.; Corno, M.; Palumbo, M.; Baricco, M. Theoretical and Experimental Studies of LiBH4-LiBr Phase Diagram. ACS Appl. Energy Mater. 2021, 4, 7327-7337. [CrossRef]

97. Saunders, N.; Miodownik, A.P. CALPHAD (Calculation of Phase Diagrams): A Comprehensive Guide; Elsevier: Amsterdam, The Netherlands, 1998; Volume 1.

98. Turchi, P.E.A.; Abrikosov, I.A.; Burton, B.; Fries, S.G.; Grimvall, G.; Kaufman, L.; Korzhavyi, P.; Rao Manga, V.; Ohno, M.; Pisch, A.; et al. Interface between quantum-mechanical-based approaches, experiments, and CALPHAD methodology. Calphad 2007, 31, 4-27. [CrossRef]

99. Dovesi, R.; Orlando, R.; Civalleri, B.; Roetti, C.; Saunders, V.R.; Zicovich-Wilson, C.M. CRYSTAL: A computational tool for the ab initio study of the electronic properties of crystals. Zeitschrift Für Krist.-Cryst. Mater. 2005, 220, 571-573. [CrossRef]

100. Dovesi, R.; Orlando, R.; Erba, A.; Zicovich-Wilson, C.M.; Civalleri, B.; Casassa, S.; Maschio, L.; Ferrabone, M.; De La Pierre, M.; D'Arco, P.; et al. CRYSTAL14: A Program for the Ab Initio Investigation of Crystalline Solids. Int. J. Quantum Chem. 2014, 114, 1287-1317. [CrossRef]

101. Dovesi, R.; Saunders, V.R.; Roetti, C.; Orlando, R.; Zicovich-Wilson, C.M.; Pascale, F.; Civalleri, B.; Doll, K.; Harrison, N.M.; Bush, I.J.; et al. CRYSTAL17 User's Manual; University of Turin (Università degli Studi di Torino): Turin, Italy, 2017.

102. Dovesi, R.; Erba, A.; Orlando, R.; Zicovich-Wilson, C.M.; Civalleri, B.; Maschio, L.; Rérat, M.; Casassa, S.; Baima, J.; Salustro, S.; et al. Quantum-mechanical condensed matter simulations with CRYSTAL. Wiley Interdiscip. Rev. Comput. Mol. Sci. 2018, 8, e1360. [CrossRef]

103. Grove, H.; Rude, L.H.; Jensen, T.R.; Corno, M.; Ugliengo, P.; Baricco, M.; Sørby, M.H.; Hauback, B.C. Halide substitution in Ca(BH 4) 2. RSC Adv. 2014, 4, 4736-4742. [CrossRef]

104. Hino, S.; Fonneløp, J.E.; Corno, M.; Zavorotynska, O.; Damin, A.; Richter, B.; Baricco, M.; Jensen, T.R.; Sørby, M.H.; Hauback, B.C. Halide Substitution in Magnesium Borohydride. J. Phys. Chem. C 2012, 116, 12482-12488. [CrossRef]

105. Albanese, E.; Corno, M.; Baricco, M.; Civalleri, B. Simulation of nanosizing effects in the decomposition of $\mathrm{Ca}(\mathrm{BH} 4) 2$ through atomistic thin film models. Res. Chem. Intermed. 2021, 47, 345-356. [CrossRef] 
106. Kim, K.J.; Montoya, B.; Razani, A.; Lee, K.-H. Metal hydride compacts of improved thermal conductivity. Int. J. Hydrogen Energy 2001, 26, 609-613. [CrossRef]

107. Baldissin, D.; Urgnani, J.; Palumbo, M.; Gagliano, S.; Baricco, M. Thermofluidodynamic modelling of hydrogen absorption and desorption in a LaNi4.8Al0.2 hydride bed. Present. MH2008 Int. Symp. Met. Syst. Reykjavik. Icel. 2008, 26, 609-613.

108. Bellosta von Colbe, J.; Ares, J.-R.; Barale, J.; Baricco, M.; Buckley, C.; Capurso, G.; Gallandat, N.; Grant, D.M.; Guzik, M.N.; Jacob, I.; et al. Application of hydrides in hydrogen storage and compression: Achievements, outlook and perspectives. Int. J. Hydrogen Energy 2019, 44, 7780-7808. [CrossRef]

109. Ley, M.; Meggouh, M.; Moury, R.; Peinecke, K.; Felderhoff, M. Development of Hydrogen Storage Tank Systems Based on Complex Metal Hydrides. Materials 2015, 8, 5891-5921. [CrossRef]

110. Utz, I.; Linder, M.; Schmidt, N.; Hu, J.J.; Fichtner, M.; Wörner, A. Experimental study of powder bed behavior of sodium alanate in a lab-scale H2 storage tank with flow-through mode. Int. J. Hydrogen Energy 2012, 37, 7645-7653. [CrossRef]

111. Utz, I.; Schmidt, N.; Wörner, A.; Hu, J.J.; Zabara, O.; Fichtner, M. Experimental results of an air-cooled lab-scale H2 storage tank based on sodium alanate. Int. J. Hydrogen Energy 2011, 36, 3556-3565. [CrossRef]

112. Pfeifer, P.; Wall, C.; Jensen, O.; Hahn, H.; Fichtner, M. Thermal coupling of a high temperature PEM fuel cell with a complex hydride tank. Int. J. Hydrogen Energy 2009, 34, 3457-3466. [CrossRef]

113. Weiss-Ungethüm, J.; Bürger, I.; Schmidt, N.; Linder, M.; Kallo, J. Experimental investigation of a liquid cooled high temperature proton exchange membrane (HT-PEM) fuel cell coupled to a sodium alanate tank. Int. J. Hydrogen Energy 2014, 39, 5931-5941. [CrossRef]

114. Urbanczyk, R.; Peinecke, K.; Meggouh, M.; Minne, P.; Peil, S.; Bathen, D.; Felderhoff, M. Design and operation of an aluminium alloy tank using doped Na3AlH6 in kg scale for hydrogen storage. J. Power Source 2016, 324, 589-597. [CrossRef]

115. Mosher, D.A.; Tang, X.; Brown, R.J.; Arsenault, S.; Saitta, S.; Laube, B.L.; Dold, R.H.; Donald, L.A. High Density Hydrogen Storage System Demonstration Using NaAlH4 Based Complex Compound Hydrides; OSTI: Golden, CO, USA, 2007.

116. Mosher, D.A.; Arsenault, S.; Tang, X.; Anton, D.L. Design, fabrication and testing of NaAlH4 based hydrogen storage systems. J. Alloys Compd. 2007, 446-447, 707-712. [CrossRef]

117. Urbanczyk, R.; Peinecke, K.; Felderhoff, M.; Hauschild, K.; Kersten, W.; Peil, S.; Bathen, D. Aluminium alloy based hydrogen storage tank operated with sodium aluminium hexahydride Na3AlH6. Int. J. Hydrogen Energy 2014, 39, 17118-17128. [CrossRef]

118. Urbanczyk, R.; Peil, S.; Bathen, D.; Heßke, C.; Burfeind, J.; Hauschild, K.; Felderhoff, M.; Schüth, F. HT-PEM Fuel Cell System with Integrated Complex Metal Hydride Storage Tank. Fuel Cells 2011, 11, 911-920. [CrossRef]

119. Na Ranong, C.; Höhne, M.; Franzen, J.; Hapke, J.; Fieg, G.; Dornheim, M.; Eigen, N.; Bellosta von Colbe, J.M.; Metz, O. Concept, Design and Manufacture of a Prototype Hydrogen Storage Tank Based on Sodium Alanate. Chem. Eng. Technol. 2009, 32, 1154-1163. [CrossRef]

120. Wellnitz, J. Hydrogen storage systems for automotive applications: Project StorHy. Int. J. Sustain. Des. 2008, 1, 93. [CrossRef]

121. Bellosta von Colbe, J.M.; Metz, O.; Lozano, G.A.; Pranzas, P.K.; Schmitz, H.W.; Beckmann, F.; Schreyer, A.; Klassen, T.; Dornheim, M. Behavior of scaled-up sodium alanate hydrogen storage tanks during sorption. Int. J. Hydrogen Energy 2012, 37, 2807-2811. [CrossRef]

122. Bellosta von Colbe, J.M.; Lozano, G.; Metz, O.; Bücherl, T.; Bormann, R.; Klassen, T.; Dornheim, M. Design, sorption behaviour and energy management in a sodium alanate-based lightweight hydrogen storage tank. Int. J. Hydrogen Energy 2015, 40, 2984-2988. [CrossRef]

123. Johnson, T.A.; Kanouff, M.P.; Dedrick, D.E.; Evans, G.H.; Jorgensen, S.W. Model-based design of an automotive-scale, metal hydride hydrogen storage system. Int. J. Hydrogen Energy 2012, 37, 2835-2849. [CrossRef]

124. Yan, M.; Sun, F.; Liu, X.; Ye, J.; Wang, S.; Jiang, L. Effects of graphite content and compaction pressure on hydrogen desorption properties of $\mathrm{Mg}(\mathrm{NH} 2) 2-2 \mathrm{LiH}$ based tank. J. Alloys Compd. 2015, 628, 63-67. [CrossRef]

125. Yan, M.Y.; Sun, F.; Liu, X.P.; Ye, J.H.; Yuan, H.P.; Wang, S.M.; Jiang, L.J. Experimental study on hydrogen storage properties of Li-Mg-N-H based tank. J. Alloys Compd. 2014, 603, 19-22. [CrossRef]

126. Lohstroh, W.; Fichtner, M.; Breitung, W. Complex hydrides as solid storage materials: First safety tests. Int. J. Hydrogen Energy 2009, 34, 5981-5985. [CrossRef]

127. Wee, J.-H. Which type of fuel cell is more competitive for portable application: Direct methanol fuel cells or direct borohydride fuel cells? J. Power Source 2006, 161, 1-10. [CrossRef]

128. Ma, J.; Choudhury, N.A.; Sahai, Y. A comprehensive review of direct borohydride fuel cells. Renew. Sustain. Energy Rev. 2010, 14, 183-199. [CrossRef]

129. Kim, J.; Kim, T. Compact PEM fuel cell system combined with all-in-one hydrogen generator using chemical hydride as a hydrogen source. Appl. Energy 2015, 160, 945-953. [CrossRef]

130. Liu, B.H.; Li, Z.P. A review: Hydrogen generation from borohydride hydrolysis reaction. J. Power Source 2009, 187, 527-534. [CrossRef]

131. Demirci, U.B.; Akdim, O.; Andrieux, J.; Hannauer, J.; Chamoun, R.; Miele, P. Sodium Borohydride Hydrolysis as Hydrogen Generator: Issues, State of the Art and Applicability Upstream from a Fuel Cell. Fuel Cells 2010, 10, 335-350. [CrossRef]

132. van Biert, L.; Godjevac, M.; Visser, K.; Aravind, P.V. A review of fuel cell systems for maritime applications. J. Power Source 2016, 327, 345-364. [CrossRef]

133. Fiori, C.; Dell'Era, A.; Zuccari, F.; Santiangeli, A.; D'Orazio, A.; Orecchini, F. Hydrides for submarine applications: Overview and identification of optimal alloys for air independent propulsion maximization. Int. J. Hydrogen Energy 2015, 40, 11879-11889. [CrossRef] 
134. Ghosh, P.C.; Vasudeva, U. Analysis of 3000T class submarines equipped with polymer electrolyte fuel cells. Energy 2011, 36, 3138-3147. [CrossRef]

135. Bicer, Y.; Dincer, I. Clean fuel options with hydrogen for sea transportation: A life cycle approach. Int. J. Hydrogen Energy 2018, 43, 1179-1193. [CrossRef]

136. Weydahl, H.; Gilljam, M.; Lian, T.; Johannessen, T.C.; Holm, S.I.; Hasvold, J.Ø. Fuel cell systems for long-endurance autonomous underwater vehicles—challenges and benefits. Int. J. Hydrogen Energy 2020, 45, 5543-5553. [CrossRef]

137. Sattler, G. Fuel cells going on-board. J. Power Source 2000, 86, 61-67. [CrossRef]

138. Swider-Lyons, K.; Deitz, D. Hydrogen Fuel Cells for Unmanned Undersea Vehicle Propulsion. ECS Trans. 2016, 75, 479-489. [CrossRef]

139. Bevan, A.I.; Züttel, A.; Book, D.; Harris, I.R. Performance of a metal hydride store on the "Ross Barlow" hydrogen powered canal boat. Faraday Discuss. 2011, 151, 353. [CrossRef]

140. Doucet, G.; Etiévant, C.; Puyenchet, C.; Grigoriev, S.; Millet, P. Hydrogen-based PEM auxiliary power unit. Int. J. Hydrogen Energy 2009, 34, 4983-4989. [CrossRef]

141. Available online: www.toshiba-energy.com (accessed on 15 February 2021).

142. Rizzi, P.; Pinatel, E.; Luetto, C.; Florian, P.; Graizzaro, A.; Gagliano, S.; Baricco, M. Integration of a PEM fuel cell with a metal hydride tank for stationary applications. J. Alloys Compd. 2015, 645, S338-S342. [CrossRef]

143. Available online: www.gknpm.com (accessed on 1 February 2021).

144. GKN Hydrogen. Available online: https://www.gknpm.com/en/innovation/hydrogen-technology/ (accessed on 1 February 2021).

145. Beaufrere, A.H.; Salzano, F.J.; Isler, R.J.; Yu, W.S. Hydrogen storage via iron-titanium for a 26 MW(e) peaking electric plant. Int. J. Hydrogen Energy 1976, 1, 307-319. [CrossRef]

146. Strickland, G.; Yu, W.S. Some Rate and Modeling Studies on the Use of Iron-Titanium Hydride as an Energy Storage Medium for Electric Utility Companies; Brookhaven National Lab: Upton, NY, USA, 1977.

147. Strickland, G.; Milau, J.; Rosso, M. Some Observations on the Effects of the Volumetric Expansion of Iron-Titanium Hydride on Vessels Built at BNL; Brookhaven National Lab: Upton, NY, USA, 1977.

148. Beaufrere, A.; Yeo, R.S.; Srinivasan, S.; McElroy, J.; Hart, G. Hydrogen-halogen energy storage system for electric utility applications. In Proceedings of the 12th Intersociety Energy Conversion Engineering Conference, Washington, DC, USA, 28 August-2 September 1977.

149. Veziroglu, T.N. Hydrogen Energy; Veziroğlu, T.N., Ed.; Springer: Boston, MA, USA, 1975; ISBN 978-1-4684-2609-0.

150. HyCARE Project. Available online: www.hycare-project.eu (accessed on 1 March 2021).

151. HyCARE focuses on large-scale, solid-state hydrogen storage. Fuel Cells Bull. 2019, 2019, 11. [CrossRef]

152. Dematteis, E.M.; Cuevas, F.; Latroche, M. HyCARE Deliverable D2.1—Optimized alloy composition. Zenodo 2020. [CrossRef]

153. Dematteis, E.M.; Cuevas, F.; Latroche, M. HyCARE Deliverable D2.2—Selected alloy characterisation. Zenodo 2020. [CrossRef]

154. Dematteis, E.M.; Cuevas, F.; Latroche, M. HyCARE Deliverable D2.3-Processing parameters. Zenodo 2020. [CrossRef]

155. Dematteis, E.M.; Cuevas, F.; Latroche, M. HyCARE Deliverable D3.2-Characterisation of powder and pellets. Zenodo 2021. [CrossRef]

156. McPhy INGRID Project. Available online: https://mcphy.com/en/achievements/ingrid (accessed on 15 January 2021).

157. Johnson, T.A.; Jorgensen, S.W.; Dedrick, D.E. Performance of a full-scale hydrogen-storage tank based on complex hydrides. Faraday Discuss. 2011, 151, 327. [CrossRef]

158. Bürger, I.; Komogowski, L.; Linder, M. Advanced reactor concept for complex hydrides: Hydrogen absorption from room temperature. Int. J. Hydrogen Energy 2014, 39, 7030-7041. [CrossRef]

159. Hu, J.; Fichtner, M.; Baricco, M. Preparation of Li-Mg-N-H hydrogen storage materials for an auxiliary power unit. Int. J. Hydrogen Energy 2017, 42, 17144-17148. [CrossRef]

160. Hu, J.; Pohl, A.; Wang, S.; Rothe, J.; Fichtner, M. Additive Effects of LiBH 4 and ZrCoH3 on the Hydrogen Sorption of the Li-Mg-N-H Hydrogen Storage System. J. Phys. Chem. C 2012, 116, 20246-20253. [CrossRef]

161. Zhang, X.; Li, Z.; Lv, F.; Li, H.; Mi, J.; Wang, S.; Liu, X.; Jiang, L. Improved hydrogen storage performance of the LiNH2-MgH2LiBH4 system by addition of ZrCo hydride. Int. J. Hydrogen Energy 2010, 35, 7809-7814. [CrossRef]

162. Baricco, M.; Bang, M.; Fichtner, M.; Hauback, B.; Linder, M.; Luetto, C.; Moretto, P.; Sgroi, M. SSH2S: Hydrogen storage in complex hydrides for an auxiliary power unit based on high temperature proton exchange membrane fuel cells. J. Power Source 2017, 342, 853-860. [CrossRef]

163. Bürger, I.; Hu, J.J.; Vitillo, J.G.; Kalantzopoulos, G.N.; Deledda, S.; Fichtner, M.; Baricco, M.; Linder, M. Material properties and empirical rate equations for hydrogen sorption reactions in $2 \mathrm{LiNH} 2-1.1 \mathrm{MgH} 2-0.1 \mathrm{LiBH} 4-3 \mathrm{wt}$ \% $\mathrm{ZrCoH} 3$. Int. J. Hydrogen Energy 2014, 39, 8283-8292. [CrossRef]

164. Lototskyy, M.V.; Tolj, I.; Davids, M.W.; Klochko, Y.V.; Parsons, A.; Swanepoel, D.; Ehlers, R.; Louw, G.; van der Westhuizen, B.; Smith, F.; et al. Metal hydride hydrogen storage and supply systems for electric forklift with low-temperature proton exchange membrane fuel cell power module. Int. J. Hydrogen Energy 2016, 41, 13831-13842. [CrossRef]

165. Standal, K.; Talevi, M.; Westskog, H. Engaging men and women in energy production in Norway and the United Kingdom: The significance of social practices and gender relations. Energy Res. Soc. Sci. 2020, 60, 101338. [CrossRef]

166. Women in Green Hydrogen. Available online: https://women-in-green-hydrogen.net/ (accessed on 15 December 2020). 